\title{
Diversity and Distribution of Prokaryotes within a Shallow-Water Pockmark Field
}

\author{
Donato Giovannelli ${ }^{1,2,3,4 *}$, Giuseppe d'Errico ${ }^{1,5}$, Federica Fiorentino ${ }^{1}$, Daniele Fattorini ${ }^{5}$, \\ Francesco Regoli ${ }^{5}$, Lorenzo Angeletti ${ }^{6}$, Tatjana Bakran-Petricioli ${ }^{7}$, Costantino Vetriani ${ }^{2,8}$, \\ Mustafa Yücel ${ }^{9}$, Marco Taviani $^{6,10}$ and Elena Manini ${ }^{1 *}$ \\ ${ }^{1}$ Institute of Marine Sciences, National Research Council, Ancona, Italy, ${ }^{2}$ Institute of Earth, Ocean and Atmospheric Science, \\ Rutgers, The State University of New Jersey, New Brunswick, NJ, USA, ${ }^{3}$ Program in Interdisciplinary Studies, Institute of \\ Advanced Studies, Princeton, NJ, USA, ${ }^{4}$ Earth-Life Science Institute, Tokyo Institute of Technology, Tokyo, Japan, \\ ${ }^{5}$ Department for Life and Environmental Science, Polytechnic University of Marche, Ancona, Italy, ${ }^{6}$ Institute of Marine \\ Sciences, National Research Council, Bologna, Italy, ${ }^{7}$ Department of Biology, Faculty of Science, University of Zagreb, \\ Zagreb, Croatia, ${ }^{8}$ Department of Biochemistry and Microbiology, Rutgers, The State University of New Jersey, New \\ Brunswick, NJ, USA, ${ }^{9}$ Institute of Marine Sciences, Middle East Technical University, Mersin, Turkey, ${ }^{10}$ Department of \\ Biology, Woods Hole Oceanographic Institution, Woods Hole, MA, USA
}

\section{OPEN ACCESS}

Edited by:

Mark Alexander Lever,

ETH Zürich, Switzerland

Reviewed by:

Jens Kallmeyer,

Helmholtz Zentrum Potsdam-GFZ,

Germany

Jeremy Dodsworth,

California State University, San

Bernardino, USA

*Correspondence: Donato Giovannelli giovannelli@elsi.jp;

Elena Manin

e.manini@ismar.cnr.it

Specialty section:

This article was submitted to

Extreme Microbiology,

a section of the journal

Frontiers in Microbiology

Received: 13 January 2016

Accepted: 01 June 2016

Published: 17 June 2016

Citation:

Giovannelli D, d'Errico G, Fiorentino F,

Fattorini D, Regoli F, Angeletti L,

Bakran-Petricioli T, Vetriani C,

Yücel M, Taviani M and Manini E (2016) Diversity and Distribution of Prokaryotes within a Shallow-Water

Pockmark Field.

Front. Microbiol. 7:941

doi: 10.3389/fmicb.2016.00941
Pockmarks are crater-like depression on the seafloor associated with hydrocarbon ascent through muddy sediments in continental shelves around the world. In this study, we examine the diversity and distribution of benthic microbial communities at shallow-water pockmarks adjacent to the Middle Adriatic Ridge. We integrate microbial diversity data with characterization of local hydrocarbons concentrations and sediment geochemistry. Our results suggest these pockmarks are enriched in sedimentary hydrocarbons, and host a microbial community dominated by Bacteria, even in deeper sediment layers. Pockmark sediments showed higher prokaryotic abundance and biomass than surrounding sediments, potentially due to the increased availability of organic matter and higher concentrations of hydrocarbons linked to pockmark activity. Prokaryotic diversity analyses showed that the microbial communities of these shallowwater pockmarks are unique, and comprised phylotypes associated with the cycling of sulfur and nitrate compounds, as well as numerous know hydrocarbon degraders. Altogether, this study suggests that shallow-water pockmark habitats enhance the diversity of the benthic prokaryotic biosphere by providing specialized environmental niches.

Keywords: pockmarks, cold seeps, hydrocarbons, prokaryotic diversity, bacteria, archaea, hydrocarbon degradation, microbial diversity

\section{INTRODUCTION}

Pockmarks are a type of cold seeps characterized by seafloor depression induced by fluids or hydrocarbon ascent through muddy sediments (Judd and Hovland, 2007). Natural gas and fluid migration to the surface create a mass defect under the seafloor generating a gravity collapse and the typical crater-like depressions (Judd and Hovland, 2007). Pockmarks generally occur in fine-grained sediments as cone-shaped circular depressions ranging from few meters to $>500 \mathrm{~m}$ in diameter and from 1 to $80 \mathrm{~m}$ in depth. Pockmarks are widespread features along passive and active continental margins and they are often present in clusters varying from few to hundreds per 
$\mathrm{km}^{2}$ (Pilcher and Argent, 2007; Forwick et al., 2009). Due to their abundance and distribution, which includes shallow-water locations, the contribution of pockmarks to global methane and hydrocarbon release could be enormous (Fleischer et al., 2001). Methane, despite its low abundance in the atmosphere, is a powerful greenhouse gas and has been recognized as one of the forcing factors for rapid climate change (Manne and Richels, 2001; Watson, 2001). Its release from the ocean floor can influence global warming, modify oceanic redox conditions and affect the global carbon cycle (Hinrichs and Boetius, 2003; Judd and Hovland, 2007; Reeburgh, 2007). Seepage of methane and other hydrocarbons can sustain locally dense populations of metazoans supported by aerobic methane and/or sulfide oxidizing prokaryotes (Boetius et al., 2000; Olu-Le Roy et al., 2004; Judd and Hovland, 2007; Taviani, 2011). While the microbial communities associated with the degradation of methane have been widely investigated in seep environments (Knittel and Boetius, 2009; Ruff et al., 2015), microbial communities associated with the natural seepage of heavier hydrocarbons have received little attention.

Previous studies carried out in the North Sea, Atlantic Ocean, and Mediterranean Sea revealed that pockmarks may represent hot-spot of biodiversity, both for the microbial community and metazoans (Olu-Le Roy et al., 2004; Bouloubassi et al., 2009; Cambon-Bonavita et al., 2009; Merkel et al., 2010; Pimenov et al., 2010; Lazar et al., 2011; Håvelsrud et al., 2012), linked to the presence of fluid and hydrocarbon seepage. In recent years, an increasing variety of hydrocarbon degrading prokaryotes has been described, mainly from the Alpha-, Delta- and Gammaproteobacteria class and Firmicutes phylum (Head et al., 2006; Kniemeyer et al., 2007; Yakimov et al., 2007; Håvelsrud et al., 2012; Jaekel et al., 2013). Members of these groups are able to degrade complex mixtures of hydrocarbons (Meckenstock and Mouttaki, 2011; Rosenberg, 2013; Abbasian et al., 2015), and often dominate communities in post-oil spill samples (Kostka et al., 2011; Mason et al., 2012; Joye et al., 2014; Kleindienst et al., 2016).

The Mediterranean Sea is a semi-closed marine system with peculiar characteristics: high deep-water temperature and homeothermy (ca. $13^{\circ} \mathrm{C}$ ), fast deep-water turnover (in the order of 11-100 years Santinelli et al., 2010) and a strong decreasing trophic gradient moving from the Western Basin to the Eastern Basin (Koppelmann et al., 2004). Pockmarks are common features on many continental margins of the Mediterranean Basin (Hovland and Curzi, 1989; Dimitrov and Woodside, 2003; Trincardi et al., 2004; Geletti et al., 2008; Taviani et al., 2013; Taviani, 2014). Despite this, the effects of the shallow-water pockmarks of the Mediterranean basin and associated seeping on the surface sediment microbial community, remain largely unknown.

Here, we have examined the diversity and distribution of benthic microbial communities associated with shallow-water pockmarks adjacent to the Middle Adriatic Ridge. The microbial diversity data were integrated with measurements of sedimentary hydrocarbons and organic matter content. Specifically, we investigated whether: (i) shallow-water pockmarks of the Middle Adriatic shelf are associated with a sedimentary hydrocarbon anomaly; (ii) the structure of the prokaryotic community differs among pockmarks and surrounding sediments and such change is significantly correlated with sediment chemistry; and (iii) the different microbial assemblages of shallow-water pockmarks are dominated by few or several phylotypes, implying a specialized or a generalized community, respectively.

\section{MATERIALS AND METHODS}

\section{Sampling Site and Procedure}

Sediment samples were collected ca. 75 nautical miles SouthEast of Ancona (Italy) during the ARCADIA oceanographic cruise (SeARch of CorAl banks in the miDdle AdrIAtic) on board the R/V Urania in March 2010. The surveyed area covers ca. $27 \mathrm{~km}^{2}$ and harbors over 200 pockmarks in a flat area at a depth of $190 \mathrm{~m}$ (Figure 1), described previously by Mazzotti et al. (1987), Taviani (2014). The sampling strategy included five different stations in close proximity of the Middle Adriatic Ridge $\left(42.8^{\circ} \mathrm{N}, 15.08^{\circ} \mathrm{E}\right)$. Stations A162, A163, A164, and A168 were situated at the center of randomly selected pockmarks, while station A169 was situated in open sediments in proximity to pockmark A164 (Figure 1 and Table 1). Three undisturbed sediment cores were collected at each station and were divided in three distinct horizons shipboard $(0-1,3-5,10-15 \mathrm{~cm})$. Surface sediment aliquots were immediately placed in gas tight vials for the determination of volatile aliphatic hydrocarbons (C5-C10). Aliquots maintained at $-20^{\circ} \mathrm{C}$ were used for the analyses of the organic matter composition, the content of semi-volatile or non-volatile aliphatic hydrocarbons (C10-C40), monoaromatic hydrocarbons (benzene, toluene, ethyl-benzene, xylene, BTEX), polycyclic aromatic hydrocarbons (PAHs), and to extract the genomic DNA of the microbial community. Samples for the determination of prokaryotic abundance and biomass were preserved in $2 \%$ (final concentration) sterile formaldehyde. Sediment sub-samples for fluorescence in-situ hybridization (FISH) were fixed in $2 \%$ formaldehyde for $1 \mathrm{~h}$ at room temperature, washed three times with phosphate-buffered saline (PBS) solution and then stored in PBS/ethanol $(1: 1 ; \mathrm{v} / \mathrm{v})$ at $-20^{\circ} \mathrm{C}$ until further processing.

\section{Characterization of Sediment Hydrocarbons}

Volatile aliphatic hydrocarbons (C5-C10), semi-volatile and non-volatile aliphatic hydrocarbons (C10-C40), monoaromatic hydrocarbons (BTEX) and PAHs were analyzed in sediments by conventional procedures based on gas-chromatography with flame ionization detector (FID), gas-chromatography and mass spectrometry, and HPLC with fluorimetric detection (Piva et al., 2011; Benedetti et al., 2014; Etiope et al., 2014). Limitations in our sampling gear prevented us from analyzing volatile aliphatic hydrocarbons between $\mathrm{C} 1$ and $\mathrm{C} 4$. Briefly, for the analyses of volatile aliphatic hydrocarbons (C5-C10), samples previously stored within gas-tight sealed vials and maintained at $-20^{\circ} \mathrm{C}$, were warmed to $80^{\circ} \mathrm{C}$ for $30 \mathrm{~min}$ : the head space gas was analyzed by gas chromatography (Perkin Elmer Clarus 500) with an Elite-5 capillary column $(30 \mathrm{~m} \times$ $0.32 \mathrm{~mm} \times 0.25 \mu \mathrm{m})$ and FID. Compounds were identified 


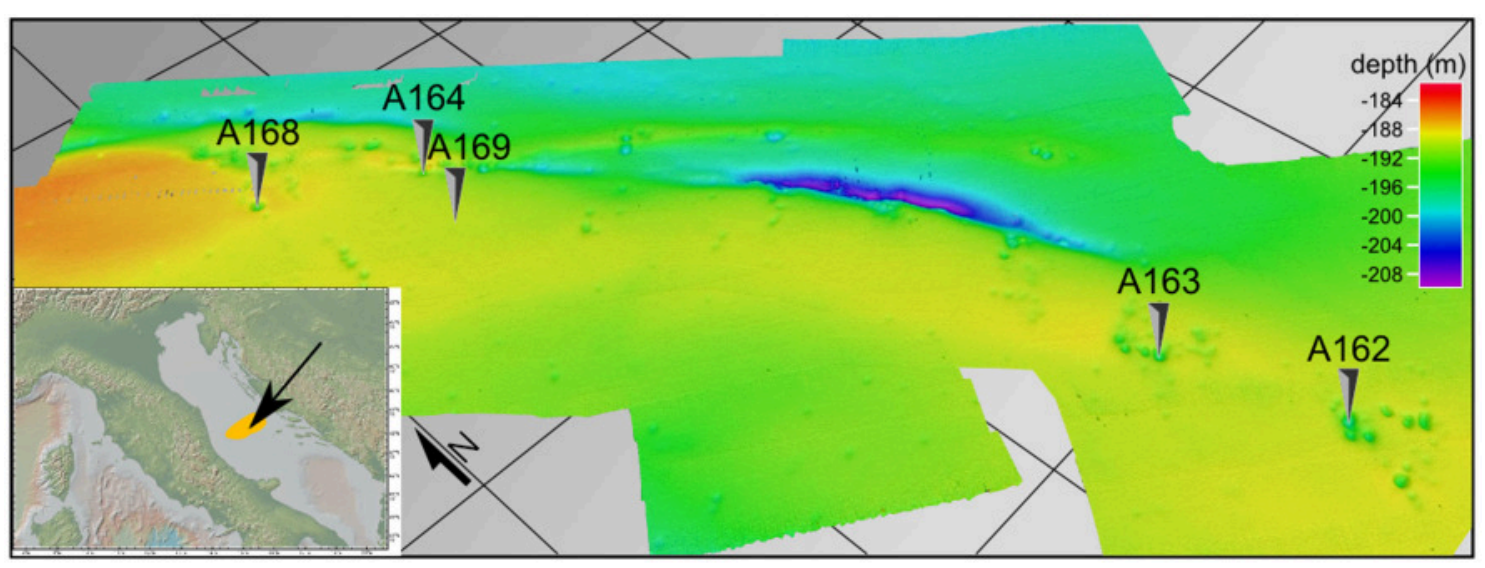

FIGURE 1 | High-resolution shaded relief DTM of the sampled pockmark field in the Middle Adriatic shelf. Several pockmarks are visible, together with the depression associated with the MAR. Sampled pockmarks and sediments are marked with a black arrow.

TABLE 1 | Details of the sampled stations and sedimentary organic matter content.

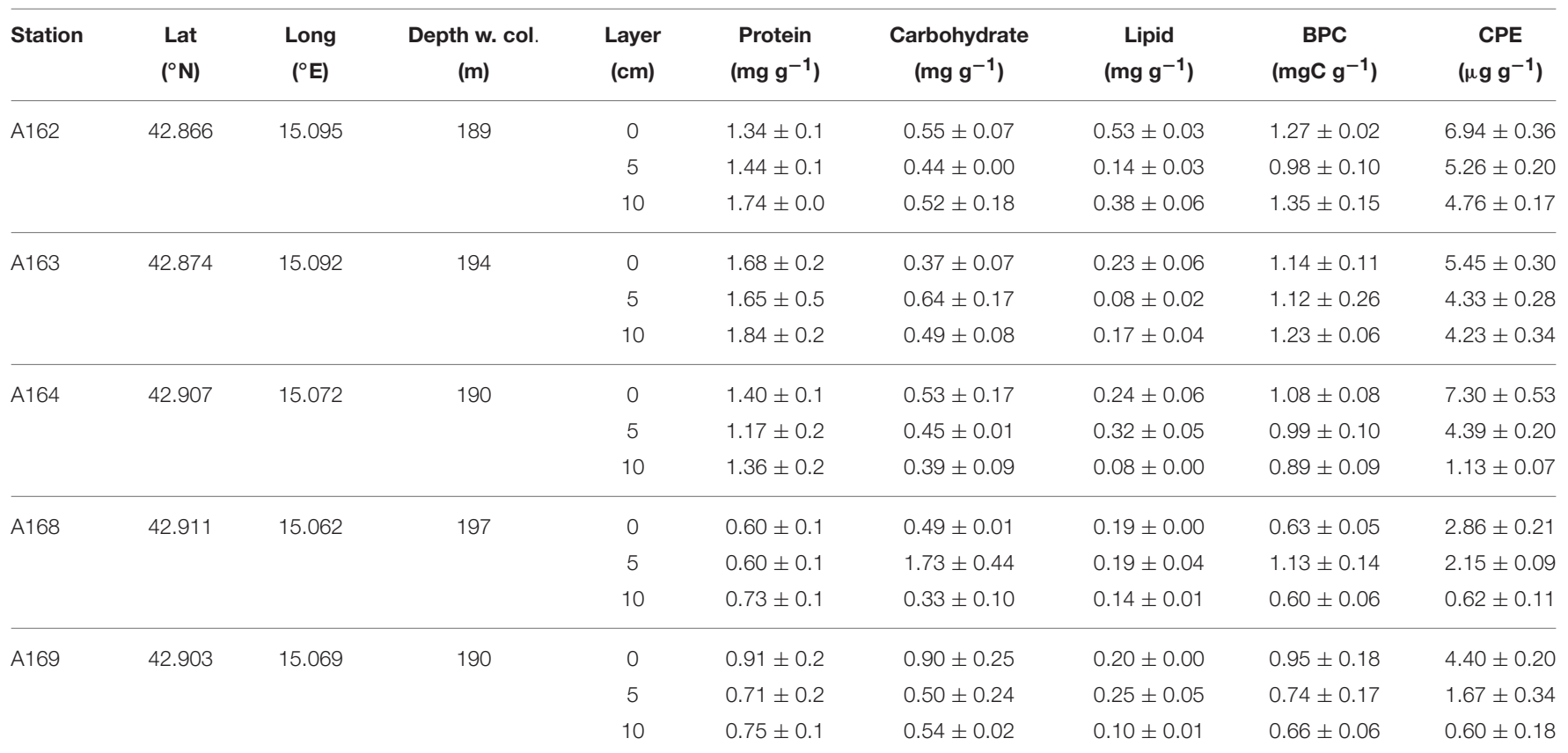

Results are reported as average \pm standard deviation. BPC, Biopolymeric organic carbon; CPE, Chloroplastic pigment equivalents.

by standardization with pure standards of analytical GC grade $n$-pentane, $n$-hexane, $n$-heptane, and $n$-decane. Semi-volatile and non-volatile aliphatic hydrocarbons (C10-C40) were extracted from sediments with hexane:acetone $(2: 1)$ in a microwave $\left(110^{\circ} \mathrm{C}\right.$ for $25 \mathrm{~min}, 800$ Watt) (Mars CEM, CEM Corporation, Matthews NC). After centrifugation at $3.000 \times \mathrm{g}$ for $10 \mathrm{~min}$, the supernatants were purified with solid-phase extraction (Phenomenex Strata-X, $500 \mathrm{mg} \times 6 \mathrm{~mL}$ plus Phenomenex Strata-FL, $1000 \mathrm{mg} \times 6 \mathrm{~mL}$ ) and then concentrated using a SpeedVac (RC1009; grade $n$-hexane and analyzed with a Perkin Elmer gas chromatograph) equipped with an Elite-5 capillary column $(30 \mathrm{~m} \times 0.32 \mathrm{~mm} \mathrm{ID} \times 0.25 \mu \mathrm{m}-\mathrm{df})$ and a FID. For quantitative determination, the system was calibrated with an unsaturated pair $n$-alkane standard mixture according to EN ISO 9377-3 (Fluka 68281). Monoaromatic hydrocarbons BTEX, benzene, toluene, ethylbenzene, xylene (orto-, meta-, para-) were analyzed using gas chromatography and mass spectrometry. Samples were extracted with $n$-hexane:acetone $(2: 1)$ in a microwave system (Microwave Digestion and Extraction System Mars-5, CEM) at $110^{\circ} \mathrm{C}$ and $800 \mathrm{~W}$ for $25 \mathrm{~min}$. After centrifugation at $3.000 \times \mathrm{g}$ for $10 \mathrm{~min}$, the supernatants were purified by solid phase extraction (Phenomenex Strata-X, $500 \mathrm{mg}$ $\times 6 \mathrm{~mL}$ plus Phenomenex Strata-FL, $1000 \mathrm{mg} \times 6 \mathrm{~mL})$ and then concentrated using a SpeedVac (RC1009; Jouan, Nantes, 
France) to dryness. Compounds were re-dissolved in analytical GC-MS grade $n$-hexane $(1 \mathrm{~mL})$ and analyzed using a GC-MS system, Varian Chrompack CP-3800 equipped with Saturn 2000 ionic trap. For the analysis of PAHs, sediment samples were extracted using $0.5 \mathrm{M}$ potassium hydroxide in methanol with microwave at $55^{\circ} \mathrm{C}$ for $20 \mathrm{~min}$ (800 Watt) (CEM, Mars System). After centrifugation at $3.000 \times \mathrm{g}$ for $10 \mathrm{~min}$, the methanol extracts were concentrated using a SpeedVac and purified with solid-phase extraction (Octadecyl C18, $500 \mathrm{mg} \times 6 \mathrm{~mL}$, Bakerbond). A final volume of $1 \mathrm{~mL}$ was recovered with pure, analytical HPLC gradient grade acetonitrile; HPLC analyses were carried out in a water-acetonitrile gradient by fluorimetric and diode array detection. The PAHs were identified according to the retention times of an appropriate pure standards solution (EPA 610 Polynuclear Aromatic Hydrocarbons Mix), and classified as low molecular weight (LMW: naphthalene, acenaphthylene, 1-methyl naphthalene, 2-methyl naphthalene, acenaphthene, fluorene, phenanthrene, anthracene) or high molecular weight (HMW: fluoranthene, pyrene, benzo(a)antrhacene, chrysene, 7,12-dimethyl-benzo(a)anthracene, benzo(b)fluoranthene, benzo(k)fluoranthene, benzo(a)pyrene, dibenzo(a,h)anthracene, benzo(g,h,i)perylene, indeno(1,2,3-cd)pyrene). Accuracy and precision were checked analyzing both pure standard solutions and reference materials (NIST 1944) and the obtained concentrations were always within the $95 \%$ confidence intervals of certified values. Aliquots of all the samples were dried in a oven at $60^{\circ} \mathrm{C}$ for at least $8 \mathrm{~h}$, up to obtain a constant weight, in order to quantify the interstitial water content, allowing to express all the analyzed chemicals as a function of the dry weight (d.w.) of the sediments.

\section{Sedimentary Geochemistry}

Frozen samples were thawed at $25^{\circ} \mathrm{C}$ and porewater was separated by centrifugation (3200 rpm) and filtering of the supernatant $(0.2 \mu \mathrm{m})$. A subsample from each depth interval was analyzed with a four-channel autoanalyzer (Seal Analytical) for nitrate+nitrite, ammonium, phosphate, and silicate using the standard colorimetric methods for nutrients (Tuğrul et al., 2014). Another subsample was used for ion chromatographic analysis. Concentrations of anions (i.e., sulfate) were determined using a Dionex AS4A-SC separation column, sodium hydroxide eluent, and ASRS-I suppressor whereas cations (i.e., magnesium) were measured with a Dionex CS12-SC separation column, methane sulfonic acid eluent and CSRS-I suppressor (Koçak et al., 2012).

\section{Sedimentary Organic Matter}

Total protein, carbohydrate, lipid, chlorophyll-a, and phaeopigments were determined as previously described (Danovaro, 2010). Concentrations were calculated using standard curves, and normalized to sediment dry weight after desiccation $\left(60^{\circ} \mathrm{C}, 24 \mathrm{~h}\right)$. Protein, carbohydrate, and lipid concentrations were converted into carbon (C) equivalents

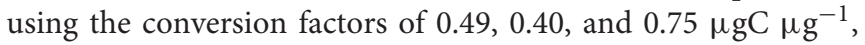
respectively (Fabiano et al., 1995). Biopolymeric organic carbon (BPC) was calculated as the sum of the carbon equivalents of protein, carbohydrate, and lipid, and was used as a proxy for the available trophic resources (Pusceddu et al., 2009).
Chloroplastic pigment equivalents are defined here as the sum of the chlorophyll-a and phaeopigment concentrations.

\section{Total Prokaryotic Number and Biomass}

Total prokaryotic counts were performed using an acridine orange staining technique (Luna et al., 2002). Briefly, tetrasodium pyrophosphate was added to $0.5 \mathrm{~g}$ of the fixed sub-samples, which were incubated for $15 \mathrm{~min}$ in the dark before sonication. The samples were then stained with acridine orange (final concentration, $0.025 \%$ ), filtered on $0.2 \mu \mathrm{m}$ poresize polycarbonate filters under low vacuum, and analyzed as described by Fry (1990) using epifluorescence microscopy (1000× magnification). Prokaryotic counts and cell dimensions were obtained using ImageJ (Abramoff et al., 2004). In order to take into account the possible effect of cell size on the carbon content three different estimate of carbon content per unit volume were used. Cells biovolumes were converted to biomass assuming an average carbon content of $400 \mathrm{fg} \mu \mathrm{gC} \mu \mathrm{m}^{-3}$ (Simon and Azam, 1989), 310 fgC $\mu \mathrm{m}^{-3}$ (Fry, 1990), and 133 fgC $\mu \mathrm{m}^{-3}$ (Simon and Azam, 1989). Total prokaryotic counts and prokaryotic biomass were normalized to sediment dry weight after desiccation $\left(24 \mathrm{~h}\right.$ at $\left.60^{\circ} \mathrm{C}\right)$.

\section{Fluorescent In-situ Hybridization}

To investigate the abundance of Bacteria and Archaea relative to total prokaryotes, FISH was used as described by Pernthaler et al. (2002). The Cy3 oligonucleotide probes used were EUB338-mix (EUB338, 5'-GCT GCC TCC CGT AGG AGT-3', EUB338-II, 5' GCA GCC ACC CGT AGG TGT-3', and EUB338-III, 5'-GCT GCC ACC CGT AGG TGT-3'), which targeted total Bacteria (Amann et al., 1990; Daims et al., 1999), ARCH915 (5'-GTG CTC CCC CGC CAA TTC CT-3'), which targeted total Archaea (Stahl and Amann, 1991) and NON338 (5'-ACT CCT ACG GGA GGC AGC-3') as the negative control (Amann, 1995). Briefly, Bacteria cell-wall was permeabilized by incubating the filters in lysozyme $\left(10 \mathrm{mg} \mathrm{mL}^{-1}\right.$ in $0.05 \mathrm{M}$ EDTA, $\mathrm{pH}$ 8.0; $0.1 \mathrm{M}$ Tris$\mathrm{HCl}, \mathrm{pH} 7.5$ ) for $60 \mathrm{~min}$ at $37^{\circ} \mathrm{C}$, followed by three washes in MilliQ water and $1 \mathrm{~min}$ incubation in $96 \%$ ethanol at room temperature. Archaea cell-wall was permeabilized by incubating the filters in Proteinase $\mathrm{K}\left(0.15 \mu \mathrm{g} \mathrm{mL}^{-1}\right.$ for $2.5 \mathrm{U} \mathrm{mg}^{-1}$ in 0.05 M EDTA, pH 8.0; 0.1 M Tris-HCl, pH 7.5, (Teira et al., 2004) for $60 \mathrm{~min}$ at $37^{\circ} \mathrm{C}$, followed by three washes in MilliQ water and $1 \mathrm{~min}$ incubation in $96 \%$ ethanol at room temperature. Fifty ng $\mu \mathrm{L}^{-1}$ of each probe were hybridized to their targets by incubating the filter at $46^{\circ} \mathrm{C}$ for $2 \mathrm{~h}$ in hybridization buffer $(0.9$ $\mathrm{M} \mathrm{NaCl}, 20$ mM Tris-HCl pH 7.4, 0.01\% SDS, 35\% Formamide). After the hybridization the filter are washed, counter stained with DAPI (4',6-diamidin-2-phenilindole), air dried, mounted on microscope slides and analyzed under the epifluorescence microscopy $(1000 \times$ magnification) with an appropriate set of filters. The Bacteria to Archaea ratio (BAR) was calculated as $\mathrm{BAR}=[(\mathrm{B}-\mathrm{A}) /(\mathrm{B}+\mathrm{A})]$ (Giovannelli et al., 2013b), where B and $\mathrm{A}$ are the abundance of Bacteria and Archaea, respectively. The BAR ratio is constrained between 1 (community composed by only Bacteria) and -1 (community composed exclusively by Archaea) and is equal to 0 if the contribution of both domain is equal to $50 \%$. 


\section{Extraction of Genomic DNA from the Microbial Community}

Genomic DNA was extracted from frozen surface sediment aliquots of each replicated core following a modified phenol:chloroform extraction procedure (Giovannelli et al., 2013a), and replicates were pooled together before amplification to reduce potential variability. Briefly, ca. $0.5 \mathrm{~g}$ of sediments were added to $850 \mu \mathrm{l}$ extraction buffer $(50 \mathrm{mM}$ Tris- $\mathrm{HCl}, 20 \mathrm{mM}$ EDTA, $100 \mathrm{mM} \mathrm{NaCl}$; $\mathrm{pH} 8.0)$ and $5 \mu \mathrm{L}$ proteinase $\mathrm{K}(20 \mathrm{mg}$ $\left.\mathrm{mL}^{-1}\right)$. Following incubation at $37^{\circ} \mathrm{C}$ for $30 \mathrm{~min}, 50 \mu \mathrm{l} \mathrm{SDS}$ (20\%) were added and incubated $1 \mathrm{~h}$ at $65^{\circ} \mathrm{C}$ with occasional mixing. After centrifugation, the pellet was washed with a second aliquot of extraction buffer and the supernatants were combined. DNA was extracted by a series of phenol:chloroform:isoamyl alcohol (25:24:1) and chloroform:isoamyl alcohol (24:1) extraction. The final supernatant was precipitated in $3 \mathrm{M}$ sodium-acetate and isopropanol, washed twice with $70 \%$ ice cold ethanol and resuspended in ultra-pure water. The integrity of $16 \mathrm{~S}$ rRNA genes was assessed by polymerase chain reaction amplification using the bacterial primers 27f-1517r (Vetriani et al., 2004). The product was visualized on $1 \%$ agarose gel stained with ethidium bromide. Multiple extractions were combined to reduce potential bias.

\section{S rRNA Gene Amplification and Tag-Encoded FLX Amplicon Pyrosequencing}

The diversity of the prokaryotic community was assessed using the variable $4(\mathrm{~V} 4)$ region of the $16 \mathrm{~S}$ rRNA gene targeted with prokaryotic universal primers (515f $5^{\prime}$-GTG CCA GCM GCC GCG GTA A-3' and 806r 5'-GGA CTA CVS GGG TAT CTA AT-3', Caporaso et al., 2011) and subjected to amplicon pyrosequencing at the Molecular Research LP facilities (Shallowater, TX, USA). Multiple PCR reactions were combined to reduce potential bias. Sequences are available through the NCBI Short Read Archive database with accession number SRP051591.

\section{Statistical and Bioinformatic Analyses}

Statistical analyses were performed with the statistical Rsoftware (R Development Core Team, 2010). The samples were investigated for differences in measured variables among the sampled stations and sediment layers using ANOVA. Where ANOVA assumptions were rejected, a more conservative level of $\mathrm{p}$ was chosen (Underwood, 1991). In case of significant differences, a HSD Tukey post-hoc test was performed. Generated 16S rRNA gene sequences were processed and analyzed using the QIIME 1.7 software package (Caporaso et al., 2010b). Briefly, sequences shorter than $200 \mathrm{bp}$, containing unresolved nucleotides, exhibiting an average quality score lower than 25 , harboring mismatches longer than $2 \mathrm{bp}$ in the forward primer, or possessing homopolymers longer than 8 bp were removed with the QIIME script split_libraries.py. This script also removes forward and reverse primer sequences and splits samples according to the tag. Subsequently, pyrosequencing noise was removed by employing the Denoiser 0.91 (Reeder and Knight) included in QIIME. Chimeric sequences were removed using UCHIME (Edgar et al., 2011), included in USEARCH (6.0.152). As the studied environment might harbor Bacteria and Archaea, which are not well represented by reference databases, we applied UCHIME in de novo mode. Subsequently, we used UCHIME in reference mode against the Greengenes Gold dataset (gold_strains_gg16S_aligned_19Mar-2011.fasta) as the reference database (DeSantis et al., 2006; Edgar et al., 2011). Operational taxonomic unit (OTUs) determination was performed with the UCLUST algorithm (Edgar, 2010) at 97\% similarity (Schloss and Handelsman, 2005) and a representative set selected employing the QIIME scripts pick_otus.py and pick_rep_set.py (Caporaso et al., 2010a). Taxonomic classification of selected reference sequences (OTUs) was performed by similarity searches using the Ribosomal Database Project classifier (Wang et al., 2007) included in QIIME. Diversity estimates (Chaol) were calculated based on rarefaction of 3000 randomly chosen sequences. Shared and unique OTUs were identified using the core_microbiome.py and make_otu_network.py QIIME script. The results were parsed with custom scripts, and used together to visualize and analyze the community network with Gephi (Bastian et al., 2009) and the Yifan $\mathrm{Hu}$ layout, a multilevel, force directed algorithm (Hu, 2005). The network structure and OTU table were employed in combination with Circos (Krzywinski et al., 2009) to visualize community composition, unique and shared OTUs and depth of taxonomic assignment. The phylogenetic tree obtained with PyNAST (Caporaso et al., 2010a) was used in Topiary Explorer (Pirrung et al., 2011) to visualize the community with tree branches collapsed at $80 \%$ of taxonomic consensus. The OTU table was imported in R to perform nonmetric multi-dimensional scaling (nMDS) and cluster analysis using the Jaccard dissimilarity and the average linkage method in Vegan (Oksanen et al., 2012). Publicly available 16S rRNA pyrotag datasets that were sequenced with the same set of primer were used for comparative purposes, and reanalyzed together with our libraries in QIIME using the same procedure. The following datasets were combined: SRS290213 (Patagonia coastal sediments), SRR192300 (Rainbow-6 deep-sea hydrothermal vent, Flores et al., 2011), DRR001439, and DRR001438 (deepsea methane seeps at the Nankai Trough, Nunoura et al., 2012).

\section{RESULTS}

\section{Geochemistry, Hydrocarbon, and Organic Matter Composition of Pockmark Sediments}

The sampled stations in this study are in proximity of a pinchlike depression oriented NW-SE and situated on the MidAdriatic Ridge (Finetti et al., 1987; Mazzotti et al., 1987). All sampled stations follow this NW-SE axis (Figure $\mathbf{1}$ and Table $\mathbf{1}$ ). Pockmark A164 is aligned with the pinch-like depression, while all other pockmark stations are situated slightly off axis. Pockmarks range from 50 to $200 \mathrm{~m}$ in diameter and 1 to $6.5 \mathrm{~m}$ in depth; they are randomly distributed in muddy sediments of the 
surveyed area, and are at times clustered in groups of 5-7. The shape is circular and annular and sometimes they are coalescent.

Sedimentary concentrations of nutrients and major cations measured in the sediment porewaters are reported in Table 2 and Figure 2. All examined cores displayed a downcore depletion of nitrate and nitrite $\left(\sum \mathrm{NO}_{\mathrm{x}}\right.$; Figure 2). Nitrate concentrations in the cores from station A164 and A168 reached close to zero already at the 3-5 cm layer, while the other stations had the nitrate minimum in deeper layers. Station A169 had lower nitrate concentrations in the surface sediments then the other sampled stations (Figure 2). All sampled station showed a downcore accumulation of ammonium while sulfate levels were more or less constant, except for the very top layer in A163, A164, and A168. Silica and phosphate concentrations also increased with increasing sediment depth in all investigated stations (Table 2). Concentrations of all other major cations did not show strong trends downcore, and were not different between stations. Pockmark station A164 was the only exception with a downcore increase in the concentrations of potassium, magnesium, and calcium.

Sedimentary concentrations of volatile aliphatic hydrocarbons (C5-C10), semi-volatile and non-volatile aliphatic hydrocarbons (C10-C40), monoaromatic hydrocarbons (BTEX), and PAHs were measured in the pockmarks and surrounding sediments to investigate the extent and nature of seepage activity (Table 3). Differences among sampled stations were observed for volatile aliphatic hydrocarbons (C5-C10), with pockmark A164 having concentrations ca. two-fold higher compared to the other stations (Table 4, ANOVA $p<0.001$ ). Semi-volatile and non-volatile aliphatic hydrocarbons (C10-C40) showed comparable values and no significant differences among the stations. Monoaromatic hydrocarbon (BTEX) concentrations were higher in stations A164 and A169; these results were mostly due to the elevated content of toluene, ethyl-benzene and xylene, which showed similar concentrations in the deeper layers of such pockmarks, while benzene always remained below detection limits. PAHs were dominated by the low molecular weight fraction (from naphthalene to anthracene) with concentrations in the order of 90-110 $\mathrm{ng} \mathrm{g}^{-1}$ (d.w.) of sediment, and no relevant differences between sampling sites.

Sampled stations differed in their sedimentary organic matter content (Figure 3 and Table 1). BPC concentrations ranged from $0.60 \pm 0.06$ to $1.27 \pm 0.02 \mathrm{mgC} \mathrm{g}^{-1}$ sediment (average \pm standard deviation) and were significantly higher at the pockmark stations A162, A163, and A164 (ANOVA $p<0.001$, Table 4). Differences between sediment surface and deeper layers were found only in station A164 and A169 (ANOVA $p<0.001$, Table 4 and Figure 3). Proteins were the dominant class of organic matter, with concentrations ranging from $0.60 \pm 0.1$ to $1.84 \pm 0.2 \mathrm{mg} \mathrm{g}^{-1}$ sediment and followed a similar trend with higher concentrations in pockmarks A162, decreasing toward NW and the surrounding sediments (Figures 1, 2). No significant differences in protein concentrations were found between the surface sediments and the deeper layers (Table 4). Chloroplastic pigment equivalents showed a higher variability between stations and sediment layers (Figure 3 and Table 1), with higher concentration in pockmark
A164 and a decreasing trend along the vertical sediment profile in all sampled stations.

\section{Diversity and Distribution of the Microbial Assemblages}

Sampled stations differed in terms of abundance, biomass, and BAR (Figure 3). Prokaryotic abundances (performed with Acridine orange staining) were found to be higher in the surface sediments of pockmark A162, showing a significant decreasing trend moving NW and into surrounding sediments (ANOVA, $p<0.001$, Table 4). Prokaryotic abundances ranged from a

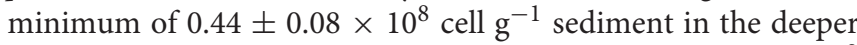
layer of station A169 to a maximum of $3.31 \pm 0.8 \times 10^{8}$ cell $\mathrm{g}^{-1}$ sediment in the surface sediments of pockmark A162 (Figure 3). Prokaryotic abundances decreased along the vertical profile in all stations (ANOVA, $p<0.001$, Table 4). Prokaryotic biomass followed a similar trend, with higher values in the surface sediments of pockmark A162 and lower in the deeper layer of the surrounding sediment. The difference in calculated prokaryotic biomass values between the low and high end estimated carbon content was a factor of 3 . Low end estimate of prokaryotic biomass were between 1 and $2.8 \mu \mathrm{gC} \mathrm{g}^{-1}$ for surface sediments, while high end estimate were as high as $8.54 \mu \mathrm{gC} \mathrm{g}^{-1}$ sediment. Prokaryotic biomass obtained with a unit volume carbon content of $310 \mathrm{fgC} \mu \mathrm{m}^{-3}$ (Fry, 1990) are reported in Figure 3.

The relative abundance of Bacteria and Archaea in the prokaryotic community was measured by mean of FISH. Active cells calculated as the contribution of total FISH targeted cells (Bacteria plus Archaea) to total prokaryotic abundance was on average of $81.6 \pm 9.2 \%$, and varied significantly among sampled stations and sediment layers (ANOVA, $p<0.001$ and $p<0.01$ respectively; Table 4 ), without showing any consistent trend (Figure 3). The BAR showed a community numerically dominated by Bacteria in all sampled stations and sediment layers, with the exception of the deeper layer of the pockmark station A162 (10-15 cm depth), where the community was almost evenly divided between Bacteria and Archaea (BAR 0.03 $\pm 0.05)$. BAR varied significantly among sampled stations and sediment layers (Table 4). Surface sediments of pockmark A163 showed a significantly lower BAR compared to the other surface sediments, with an average Archaea contribution of $38.23 \%$.

The prokaryotic diversity in surface sediments $(0-1 \mathrm{~cm}$ layer) was assessed by mean of tag-encoded FLX amplicon pyrosequencing of the variable region V4 of the $16 \mathrm{~S}$ rRNA gene with prokaryotic universal primers. A total of 30,200 sequences were generated and clustered in 5916 OTUs. Of the total obtained sequences, $9.1 \%$ could not be assigned to any known phylum, while of the remaining sequences $10.7 \%$ were classified as Archaea and $80.2 \%$ as Bacteria. The number of unclassified prokaryotic sequences was lower in station A169 than the average of pockmark stations (6.7\% against 9.75\%). Rarefaction curve analysis showed that, on average, pockmark stations had higher prokaryotic diversity if compared to surrounding sediments (Figure 4). Despite these differences in total diversity, the sampled stations showed a similar community structure of the most abundant phyla (Figure 5, circle a). The community 
TABLE 2 | Summary of the geochemical species measured in the sediment pore water along the sedimentary profile.

\begin{tabular}{|c|c|c|c|c|c|c|c|c|c|c|c|}
\hline Station & Layer (cm) & $\begin{array}{c}\sum \mathrm{NO}_{\mathrm{x}} \\
(\mu \mathrm{M})\end{array}$ & $\begin{array}{l}\mathrm{NH}_{4}^{+} \\
(\mu \mathrm{M})\end{array}$ & $\begin{array}{l}\mathrm{SO}_{4}^{2-} \\
(\mathrm{mM})\end{array}$ & $\begin{array}{c}\mathrm{PO}_{4}^{3-} \\
(\mu \mathrm{M})\end{array}$ & $\begin{array}{c}\mathbf{S i} \\
(\mu \mathrm{M})\end{array}$ & $\begin{array}{c}\mathrm{Br} \\
(\mu \mathrm{M})\end{array}$ & $\begin{array}{l}\mathrm{Na}^{+} \\
(\mathrm{mM})\end{array}$ & $\begin{array}{c}\mathrm{K}^{+} \\
(\mathrm{mM})\end{array}$ & $\begin{array}{l}\mathrm{Mg}^{2+} \\
(\mathrm{mM})\end{array}$ & $\begin{array}{l}\mathrm{Ca}^{2+} \\
(\mathrm{mM})\end{array}$ \\
\hline \multirow[t]{5}{*}{ A162 } & $0-1$ & 23.5 & 119.2 & 29.6 & 2.0 & 70.7 & 707.4 & 533.3 & 9.3 & 51.3 & 8.7 \\
\hline & $1-3$ & 11.1 & 109.0 & 29.8 & 2.2 & 95.8 & 717.3 & 532.4 & 9.7 & 62.6 & 9.4 \\
\hline & $3-5$ & 4.6 & 116.2 & 28.6 & 2.3 & 120.5 & 687.9 & 519.2 & 7.6 & 59.7 & 9.1 \\
\hline & $5-10$ & 1.2 & 116.3 & 28.9 & 2.8 & 177.5 & 703.1 & 525.1 & 10.3 & 63.6 & 13.8 \\
\hline & $10-15$ & 0.6 & 146.1 & 29.6 & 3.1 & 168.8 & 711.3 & 522.9 & 9.9 & 62.7 & 9.2 \\
\hline \multirow[t]{5}{*}{ A163 } & $0-1$ & 30.6 & 35.7 & 26.4 & 1.9 & 87.1 & 637.2 & 483.2 & 8.5 & 45.2 & 9.3 \\
\hline & $1-3$ & 18.3 & 117.2 & 29.5 & 2.4 & 100.0 & 703.8 & 521.1 & 8.5 & 60.5 & 8.6 \\
\hline & $3-5$ & 8.8 & 129.7 & $\mathrm{Na}$ & 2.6 & 144.1 & na & na & na & na & na \\
\hline & $5-10$ & 4.2 & 164.9 & 28.6 & 2.5 & 147.5 & 682.3 & 512.8 & 9.7 & 58.5 & 9.8 \\
\hline & $10-15$ & 4.5 & 180.5 & 28.2 & 3.3 & 182.6 & 684.6 & 520.4 & 8.7 & 58.9 & 11.2 \\
\hline \multirow[t]{5}{*}{ A164 } & $0-1$ & 33.4 & 99.0 & 23.8 & 2.2 & 73.9 & 589.2 & 448.2 & 8.0 & 37.5 & 6.6 \\
\hline & $1-3$ & 13.8 & 121.7 & 31.2 & 2.6 & 98.8 & 752.5 & 549.6 & 9.6 & 61.8 & 9.4 \\
\hline & $3-5$ & 0.6 & 45.0 & 31.1 & 2.7 & 119.2 & 751.6 & 555.5 & 9.7 & 61.8 & 9.1 \\
\hline & $5-10$ & 0.6 & 63.0 & 30.5 & 3.0 & 131.4 & 734.8 & 540.2 & 9.1 & 60.7 & 10.4 \\
\hline & $10-15$ & 1.9 & 127.8 & 29.4 & 3.5 & 172.7 & 715.7 & 543.2 & 9.3 & 62.0 & 9.5 \\
\hline \multirow[t]{5}{*}{ A168 } & $0-1$ & 24.6 & 74.3 & 25.9 & 2.1 & 57.9 & 628.6 & 462.7 & 8.2 & 41.3 & 8.4 \\
\hline & $1-3$ & 9.3 & 102.1 & 29.9 & 2.4 & 100.6 & 724.1 & 538.1 & 8.8 & 65.9 & 9.4 \\
\hline & $3-5$ & 0.6 & 3.6 & 28.6 & 2.9 & 125.6 & 694.8 & 515.9 & 9.0 & 64.0 & 9.0 \\
\hline & $5-10$ & 0.9 & 43.4 & 29.7 & 3.0 & 126.4 & 724.1 & 536.4 & 9.6 & 69.7 & 9.9 \\
\hline & $10-15$ & 0.8 & 45.2 & 27.3 & 3.2 & 123.6 & 672.0 & 505.2 & 8.5 & 60.2 & 8.7 \\
\hline \multirow[t]{5}{*}{ A169 } & $0-1$ & 11.3 & 1.5 & 28.5 & 2.4 & 73.2 & 690.2 & 505.0 & 9.4 & 44.2 & 8.4 \\
\hline & $1-3$ & 21.3 & 98.4 & 27.8 & 2.5 & 68.8 & 889.0 & 668.7 & 10.2 & 68.6 & 11.2 \\
\hline & $3-5$ & 5.4 & 97.5 & 29.3 & 2.9 & 96.3 & 709.1 & 518.0 & 9.0 & 53.8 & 9.8 \\
\hline & $5-10$ & 2.0 & 66.4 & 30.4 & 3.2 & 114.1 & 749.1 & 556.2 & 9.3 & 60.5 & 9.2 \\
\hline & $10-15$ & na & na & $\mathrm{Na}$ & na & na & na & na & na & na & na \\
\hline
\end{tabular}

$\sum \mathrm{NO}_{x}=\mathrm{NO}_{3}^{-}+\mathrm{NO}_{2}^{-} ; \mathrm{na}=$ not available.

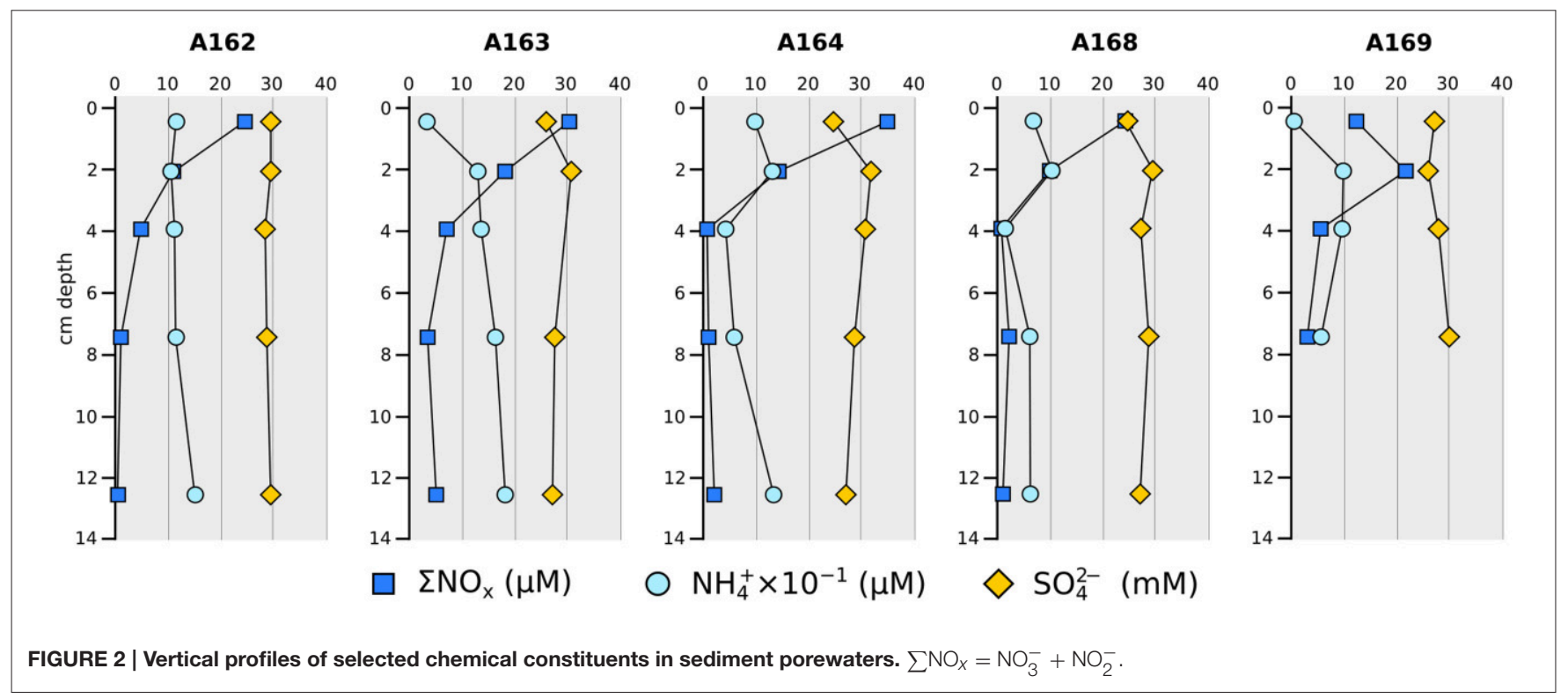


TABLE 3 | Summary of hydrocarbon concentrations in sampled stations integrated over the sediment layer: C5-C10, volatile aliphatic hydrocarbons from C5 to C10; C10-C40, semi-volatile and non-volatile aliphatic hydrocarbons from C10 to C40; BTEX, monoaromatic hydrocarbons (benzene, toluene, ethyl-benzene, xylene); PAH, polycyclic aromatic hydrocarbons, low molecular weight (low), high molecular weight (high), and total (tot).

\begin{tabular}{|c|c|c|c|c|c|c|}
\hline Station & $\begin{array}{l}\text { C5-C10 } \\
\left(\mathrm{ng} \mathrm{g}^{-1}\right)\end{array}$ & $\begin{array}{l}\text { C10-C40 } \\
\left(\mu \mathrm{g} \mathrm{g}^{-1}\right)\end{array}$ & $\begin{array}{c}\text { BTEX } \\
\left(n g^{-1}\right)\end{array}$ & $\begin{array}{l}\mathrm{PAH}_{\text {low }} \\
\left(\mathrm{ng} \mathrm{g}^{-1}\right)\end{array}$ & $\begin{array}{l}\mathrm{PAH}_{\text {high }} \\
\left(\mathrm{ng} \mathrm{g}^{-1}\right)\end{array}$ & $\begin{array}{c}\mathrm{PAH}_{\text {tot }} \\
\left(\mathrm{ng} \mathrm{g}^{-1}\right)\end{array}$ \\
\hline A162 & $158.5 \pm 31$ & $29.2 \pm 4.9$ & $31.6 \pm 7.6$ & $98.5 \pm 41.2$ & $10.1 \pm 2.8$ & $108.6 \pm 43.9$ \\
\hline A163 & $192.2 \pm 153.9$ & $25.4 \pm 11.8$ & $15.6 \pm 12.1$ & $94 \pm 17$ & $4.7 \pm 0.8$ & $98.6 \pm 16.2$ \\
\hline A164 & $438.6 \pm 169.3$ & $29.5 \pm 9.6$ & $181.5 \pm 253.9$ & $92.7 \pm$ na & $5.1 \pm$ na & $97.8 \pm$ na \\
\hline A168 & $152.9 \pm 6.4$ & $24.9 \pm 8.3$ & $<0.5$ & $90.7 \pm 21.6$ & $15.7 \pm 15.3$ & $122.9 \pm 9.1$ \\
\hline A169 & $161.8 \pm 5.4$ & $22.4 \pm 8.0$ & $278.3 \pm 149.4$ & $110.9 \pm 5.6$ & $10.1 \pm 6.7$ & $121 \pm 2.2$ \\
\hline
\end{tabular}

Mean value and standard deviation are reported, concentrations are referred to the dry weight (d.w.) of the sediments; na, not available.

TABLE 4 | Results of ANOVA analysis on the main measured variables.

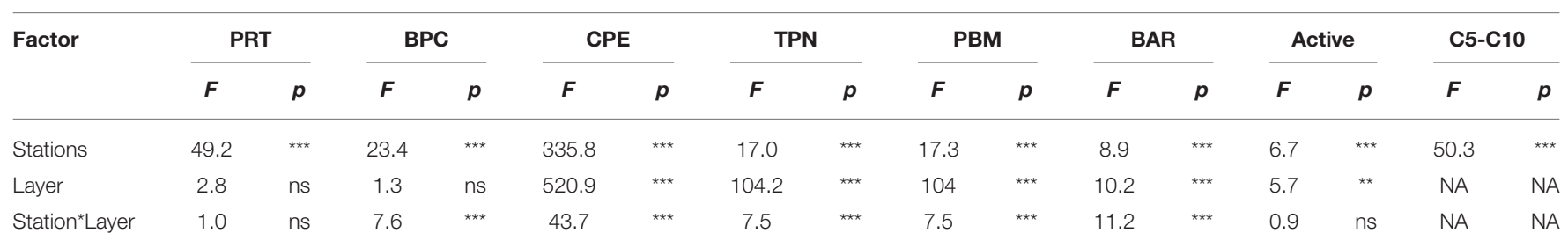

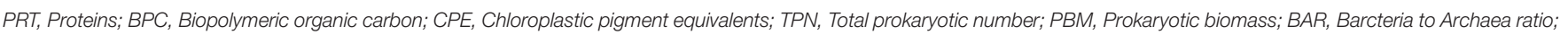
Active, Fraction of active Prokaryotes; C5-C10, Volatile aliphatic hydrocarbons. NA, not available; $n s, p>0.05 ;{ }^{*} p<0.05 ;{ }^{* \star} p<0.01 ;{ }^{* \star *} p<0.001$.

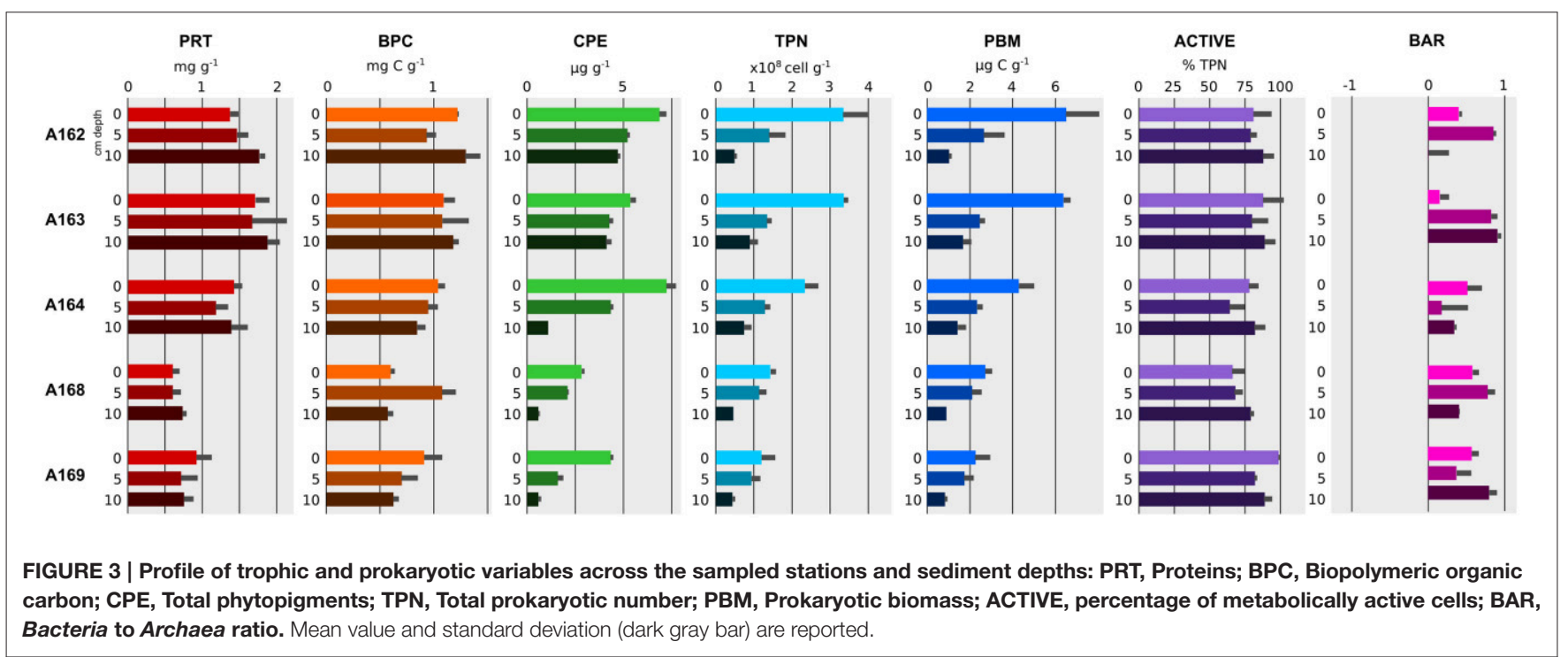

was numerically dominated by the Firmicutes (34.1\% on average), followed by the Proteobacteria (18.9\%), Planctomycetes (10.5\%), and Thaumarchaeota (10.5\%). The sampled stations showed small differences in the relative abundance of these Phyla, with station A169 having the higher percentage of Proteobacteria (24.8\%) and station A168 having the higher abundance of Thaumarchaeota (13.6\%). Overall, 34 phyla were identified, with 14 candidate divisions with no clear phylogenetic position. All major marine phyla were represented, with 21 of those passing the $0.1 \%$ cut-off and only 11 with abundances above $1 \%$ (Table 5 ).

Within the Firmicutes phylum, the Bacilli class dominated the retrieved sequences in all samples, with an average relative contribution of $34 \%$. The most abundant OTU (OTU 5181) within the phylum constituted on average $19.8 \%$ of the retrieved sequences, and was related to Bacillus aquimaris (accession number AF483625.1, 99.2\% similarity, Table 6), a common Gram-positive whose closest cultured relatives have been isolated in different environmental settings. The Proteobacteria phylum was numerically dominated by the class Gammaproteobacteria, and mostly represented by the order Alteromonadales. Sequences related to this group significantly differed in abundance among stations reaching $7.8 \%$ in sediment station A169, while comprised between 0.001 and 1.3\% (average $0.4 \%$ ) in the pockmarks. These sequences were represented by a 


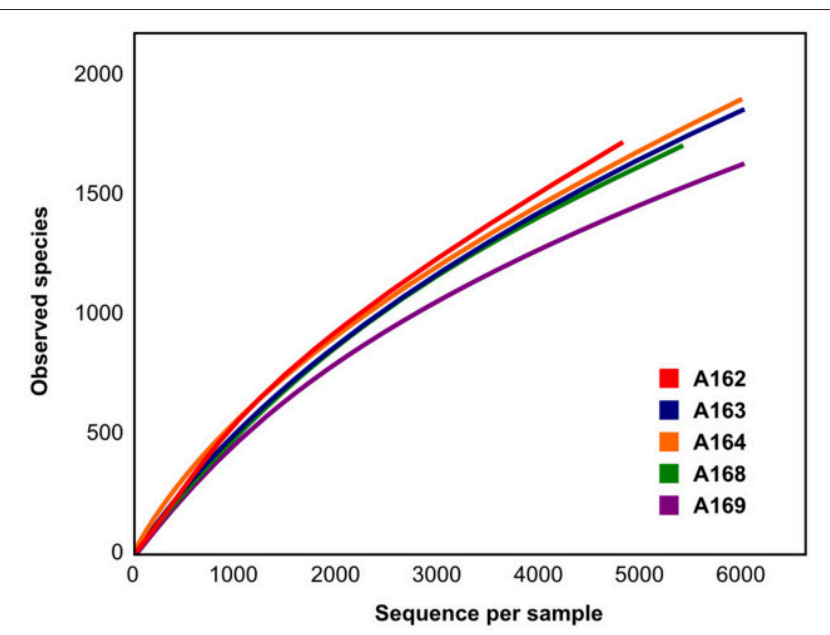

FIGURE 4 | Rarefaction curve for the 16S rRNA gene pyrotag sequences.

single dominant OTU (OTU 5045), related to Alteromonas sp. M71_D56 (acc. num. FM992724.1, 99\% similarity) isolated from the Eastern Mediterranean deep-sea. Members related to the genus Thioprofundus, within the order Chromatiales, were the second most abundant group within the Gammaproteobacteria, and represented on average $2.3 \%$ of the retrieved sequences, with an average similarity to Thioprofundus lithotrophicum of 95\% (acc. num. AB468957). Alphaproteobacteria and Deltaproteobacteria were the second most abundant class within the Proteobacteria with relative average abundances of 3.8 and $2.9 \%$, respectively. Sequences in the Alphaproteobacteria class were mainly related to the Rhizobiales and Rhodospirillales order. Most of the retrieved Deltaproteobacteria were related to the Mixococcales and candidate division NB1-j, amounting collectively to $1.9 \%$ of the total sequences. Members of the Desulfuromonadaceae, Nitrospinaceae, and Geobacteraceae families were also recovered (although with relative abundances below $0.1 \%)$. Sequences related to the synthrophic sulfate reducers order Syntrophobacterales, amounting on average to $0.25 \%$ of the reads, were also retrieved in the libraries. Betaproteobacteria and Epsilonproteobacteria related sequences were rare in all investigated samples, with relative abundances on average of 0.14 and $0.02 \%$ respectively. Betaproteobacteria were absent from station A163, while Epsilonproteobacteria related sequences were represented by singleton in all samples with the exception of pockmark A164. We also identified in our libraries the presence of the candidate division NC10 (on average $1.3 \%$ of the community), with an average similarity of $89.5 \%$ to cadidatus Methylomirabilis oxifera. Sequences related to the Thaumarcheota phylum were the third most abundant group in all sample sediments, with higher relative abundances in pockmark station A162 and A164. The average similarity to candidatus Nitrosopumilus maritimus (acc. num. CP000866.1) and candidatus Nitrosoarchaeum limnia (acc. num. CM001159.1) was 92.2 and 91.3\%, respectively.
The relative abundance of rare phyla differed significantly among station. Cluster and nMDS analyses carried out on the microbial diversity revealed that sediment station A169 clustered on its own, as did pockmark station A164, while pockmark station A162A, A163, and A168 shared a more similar community (Figure 6B). Network analysis revealed that the majority of identified OTUs were station specific (Figure 7). The number of specific OTUs (i.e., present only in one of the libraries) was equal to 4405 (of 5916 OTUs total). Station A162, A163, and A164 had the highest number of specific OTUs and were not evenly distributed among taxa.

\section{DISCUSSION}

Hydrocarbon fluid venting in the Adriatic Sea (Mediterranean Sea) is a well-known phenomenon (Hovland and Curzi, 1989; Conti et al., 2002; Curzi, 2013, and references therein), as gas reservoirs are widely distributed in the continental shelf in the Plio-Pleistocene sediments (Stefanon, 1967; Curzi and Veggiani, 1985; Mazzotti et al., 1987). According to the literature the presence of "bubbling" and "smoke" on the surface was previously reported for the study area by fishermen in the 1970's (Conti et al., 2002; Curzi, 2013) indicating active seeping. Despite several studies describing the pockmarks features and the underlying geological structures of this area (Stefanon et al., 1983; Curzi and Veggiani, 1985; Mazzotti et al., 1987; Hovland and Curzi, 1989; Trincardi et al., 2004; Geletti et al., 2008), there is little information available on the nature of seepage, or the impact on the microbial community. We present here a multidisciplinary investigation of the pockmark field in proximity of the Middle Adriatic Ridge, integrating analyses on the sedimentary geochemistry and hydrocarbon and organic matter composition with the investigation of the diversity and distribution of the microbial assemblages.

Previous studies linked pockmarks in the Central Adriatic to gas escape in connection with halokinetic activity of deepseated Triassic evaporites, as evidenced by the presence of bright spots and gas chimney in the sediment underling the pockmarks above and around the salt structure that forms the Middle Adriatic Ridge (Geletti et al., 2008). The stations sampled in this study were part of coalescent pockmarks and linear pockmark clusters (Figure 1), with the exception of station A168 (a unit pockmark) and station A169 situated in the surrounding sediments. The presence of coalesced pockmarks suggests the presence of periodic, rather than continuous, gas or fluid bursts through the seafloor (Pilcher and Argent, 2007; Hovland et al., 2010). Similar episodic events have been previously described for cold-seeps and mud volcanoes (Newton et al., 1980; Pilcher and Argent, 2007; Hovland et al., 2010), and the temporal variability in fluid emissions may greatly influence sedimentary chemistry and the diversity and distribution of microbial communities.

The sampled stations did not differ greatly in the downcore profile of nutrients and major cations (Figure 2 and Table 2). All stations present a rapid depletion of nitrate+nitrite moving downcore, consistent with the reduction of reactive oxidized 


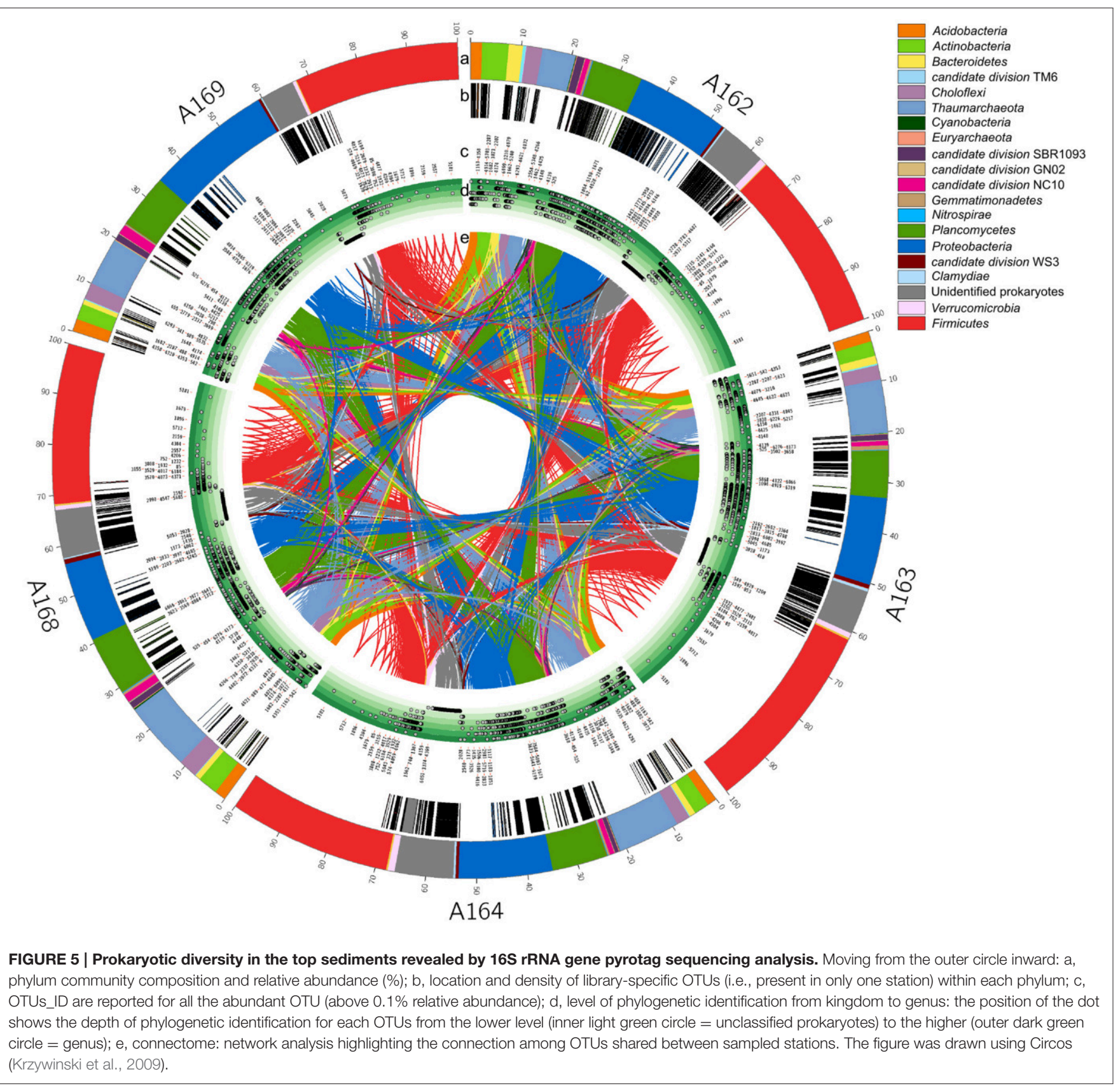

nitrogen coupled to organic matter degradation (Devol, 2015) or potentially nitrate-driven anaerobic oxidation of hydrocarbons (see below). In station A164 and A168 the concentrations of nitrate+nitrite quickly dropped below $1 \mu \mathrm{M}$ in the 3$5 \mathrm{~cm}$ sediment layer, suggesting a faster use of the oxidized nitrogen species in these stations. Overall downcore depletion of nitrate+nitrite is consistent with denitrification pathways, which probably dominated on the top $4-5 \mathrm{~cm}$ of the sediment. This could also explain the downcore accumulation of ammonium indicating that release from organic matter degradation was dominant over other ammonia-consuming processes. Supporting this idea is the downcore steady increase in phosphate and silica, which are also released from organic matter degradation (Dale et al., 2014). The lower ammonia concentration on the surface sediments of stations A163 and A169 could be linked to bacterial consumption, precipitation, and/or an increased rate of diffusion near the surface.

Sulfate levels were more or less constant between stations and moving downcore, with the exception of the surface sediments of stations A163, A164, and A168 (Figure 2). In these stations there was a lower surface sulfate concentration compared to stations A162 and a169. Also a slight decrease in sulfate concentrations moving downcore was present, which could indicate sulfate reduction processes. 
TABLE 5 | Phyla with relative abundance above $0.1 \%$ in surface sediments 16S rRNA gene libraries.

\begin{tabular}{|c|c|c|c|c|c|c|}
\hline \multirow[b]{2}{*}{ Phylum } & \multicolumn{6}{|c|}{ Abundance } \\
\hline & $\begin{array}{c}\text { Average } \\
(\%)\end{array}$ & $\begin{array}{c}\text { A162 } \\
(\%)\end{array}$ & $\begin{array}{c}\text { A163 } \\
(\%)\end{array}$ & $\begin{array}{c}\text { A164 } \\
(\%)\end{array}$ & $\begin{array}{c}\text { A168 } \\
\text { (\%) }\end{array}$ & $\begin{array}{c}\text { A169 } \\
(\%)\end{array}$ \\
\hline \multicolumn{7}{|l|}{ ABOVE 1\% } \\
\hline Firmicutes & 34.10 & 35.90 & 38.20 & 32.10 & 31.70 & 32.50 \\
\hline Proteobacteria & 18.90 & 18.20 & 17.30 & 18.50 & 15.70 & 24.80 \\
\hline Thaumarchaeota & 10.50 & 6.60 & 10.60 & 12.40 & 13.60 & 9.50 \\
\hline Planctomycetes & 10.50 & 10.10 & 9.20 & 10.80 & 11.60 & 10.60 \\
\hline Unc. Prokaryotes & 9.10 & 9.00 & 8.70 & 11.60 & 9.50 & 6.60 \\
\hline Actinobacteria & 3.60 & 5.20 & 2.90 & 3.00 & 4.00 & 3.10 \\
\hline Chloroflexi & 3.20 & 3.20 & 2.80 & 2.70 & 3.80 & 3.30 \\
\hline Acidobacteria & 2.20 & 2.30 & 2.00 & 2.00 & 2.20 & 2.60 \\
\hline Bacteroidetes & 1.50 & 2.80 & 1.50 & 1.20 & 1.10 & 0.90 \\
\hline NC10 & 1.30 & 0.90 & 0.90 & 1.00 & 1.60 & 2.00 \\
\hline Gemmatimonadetes & 1.20 & 1.50 & 1.00 & 0.80 & 1.30 & 1.20 \\
\hline Verrucomicrobia & 1.00 & 1.40 & 1.00 & 1.30 & 0.80 & 0.70 \\
\hline \multicolumn{7}{|c|}{ BETWEEN 1 AND $0.1 \%$} \\
\hline SBR1093 & 0.60 & 0.50 & 0.70 & 0.60 & 0.80 & 0.50 \\
\hline Nitrospirae & 0.50 & 0.40 & 0.90 & 0.40 & 0.40 & 0.30 \\
\hline TM6 & 0.40 & 0.30 & 0.60 & 0.40 & 0.30 & 0.30 \\
\hline Chlamydiae & 0.30 & 0.60 & 0.30 & 0.10 & 0.10 & 0.20 \\
\hline WS3 & 0.30 & 0.20 & 0.40 & 0.40 & 0.30 & 0.20 \\
\hline Euryarchaeota & 0.20 & 0.20 & 0.20 & 0.20 & 0.10 & 0.10 \\
\hline OP3 & 0.20 & 0.00 & 0.20 & 0.30 & 0.10 & 0.20 \\
\hline Cyanobacteria & 0.10 & 0.10 & 0.10 & 0.10 & 0.20 & 0.00 \\
\hline GN02 & 0.10 & 0.10 & 0.20 & 0.10 & 0.10 & 0.10 \\
\hline NKB19 & 0.10 & 0.10 & 0.10 & 0.10 & 0.20 & 0.00 \\
\hline
\end{tabular}

Hydrocarbon concentrations in the sampled sediments were on average 1 order of magnitude lower compared to the few records of sedimentary hydrocarbons measured in deep-sea pockmarks worldwide (Olu-Le Roy et al., 2004; Boitsov et al., 2009; Nickel et al., 2013), but generally higher than those typical of pristine coastal areas (Benedetti et al., 2014; Etiope et al., 2014). In particular, concentrations of volatile hydrocarbons (C5-C10) and BTEX detected in A164 and A169 sediments (Table 3) were significantly higher also if compared to coastal areas with documented seepage activities of gas and oil (Benedetti et al., 2014; Etiope et al., 2014). The highest levels of volatile hydrocarbons found in pockmark A164 (2.5-fold higher than other stations) could be explained by the position of this site, situated directly above the Middle Adriatic Ridge, where previous studies evidenced active diapirism and suggested active fluid venting (Geletti et al., 2008). Although semi-volatile and nonvolatile aliphatic hydrocarbons (C10-C40) and PAHs did not appear particularly elevated in the investigated sites, the overall results of this study demonstrated the presence of a hydrocarbon anomaly associated with the pockmark field. In previous studies, pockmarks have been described to be periodically active, perhaps only showing measurable fluid flow during special external events, such as extreme low pressure, extreme low tides, storm surges, or during increased fluid pressure (Hovland et al., 2002, 2010; Pilcher and Argent, 2007). The overall distribution of hydrocarbons concentrations along a SE-NW axis follows the alignment of the sampled pockmarks with the Middle Adriatic Ridge. Overall, these observations indicate that the pockmarks located in the proximity of the Middle Adriatic Ridge are associated with a sedimentary hydrocarbon anomaly and suggest that these sites are active, or have been active in the recent past.

The organic matter content of the pockmark sediments was comparable to deep-sea stations sampled previously in the Mediterranean Sea (Giovannelli et al., 2013b), and ca. 3 times lower that those measured in Adriatic coastal stations (Molari et al., 2012). Higher value of BPC and proteins were measured in SE pockmarks A162, A163, and A164 compared to station A168 and surrounding sediments A169 (Figure 3). The same SE-NW decreasing trend was observed for the CPE. Since all stations were in close proximity (within a $4 \mathrm{~km}$ radius) and were at similar depths, we assumed similar input of organic carbon from the water column. This implies that the measured differences in organic matter quantity and quality may be due to local processes and may reflect a complex interplay between biotic and abiotic factors over time (Hedges and Keil, 1995; Wakeham and Canuel, 2006). Measured nitrate+nitrite and ammonia concentrations differed in their downcore profiles between stations, with faster depletion of nitrate+nitrite in stations A164 and A168. All together our results indicate that pockmarks clustering in close proximity to each other may still diverge in terms of chemistry and sedimentary organic matter content, possibly connected to different stages of activity and successional status previously described for mud volcanoes (Neurauter and Roberts, 1994).

Higher benthic diversity has been associated with pockmark structures in the Mediterranean Sea (Zeppilli et al., 2012; Taviani et al., 2013; Sandulli et al., 2015), in the Atlantic Ocean (OluLe Roy et al., 2007), and North Sea (Dando et al., 1991; Dando, 2001), as well as at several other locations (Judd and Hovland, 2007). In pockmarks, spatially heterogeneous microbial and faunal assemblages have been reported in the past (Dando et al., 1991; Levin, 2005), possibly connected to differences in fluid regimes among pockmarks situated in the same fields. Prokaryotic abundances measured in this study were on average in line with other environments at comparable depth. There was a clear decrease in microbial biomass as the depth of the sediment layers increased, as previously described in other studies in the Mediterranean Sea (Corinaldesi et al., 2011; Molari et al., 2012; Giovannelli et al., 2013a). Prokaryotic biomass was comparable to other environments at similar depth, also when using more conservative estimates of the per cell carbon content. Generally, the decrease of microbial cell counts along the sediment vertical profile is the result of decreasing organic carbon quality and availability in aged buried sediments (Parkes et al., 2000). However, other abiotic and biotic factors have to be taken into account (Molari et al., 2012). In our studies the measured differences in nutrient and major cations concentrations did not explain the observed trends. The differences in prokaryotic abundances and biomass between the sampled stations correlates with higher hydrocarbon and sedimentary matter concentrations within the pockmarks, indicating a possible role of fluid circulation in controlling prokaryotic distribution. As previously described for the hydrocarbon content (especially for the volatile 
TABLE 6 | Taxonomic assignment and closest relative of the OTUs with relative abundance above $1 \%$ in any of the sampled station.

\begin{tabular}{|c|c|c|c|c|c|c|c|c|c|c|c|}
\hline \multirow[t]{2}{*}{ \#OTU ID } & \multicolumn{5}{|c|}{ Relative Abundance ${ }^{a}$} & \multicolumn{3}{|c|}{ QIIME Assigned taxonomy } & \multirow[t]{2}{*}{ Closest Relative } & \multirow[t]{2}{*}{ Identity (\%) } & \multirow[t]{2}{*}{ Acc. Num. } \\
\hline & A162 & A163 & A164 & A168 & A169 & Phylum & Class & Order & & & \\
\hline 4148 & 1.74 & 2.67 & 2.83 & 2.55 & 1.8 & Thaumarchaeota & - & Cenarchaeales & $\begin{array}{l}\text { Ca. Nitrosopumilus } \\
\text { koreensis }\end{array}$ & 97 & NR_102904.1 \\
\hline 4425 & 0.44 & 0.82 & 0.94 & 1.80 & 0.79 & Thaumarchaeota & - & Cenarchaeales & $\begin{array}{l}\text { Ca. Nitrosopelagicus } \\
\text { brevis }\end{array}$ & 97 & CP007026.1 \\
\hline 5181 & 12.32 & 10.92 & 10.26 & 7.12 & 5.79 & Firmicutes & Bacilli & Bacillales & Bacillus aquimaris & 99 & AF483624.1 \\
\hline 1896 & 3.73 & 3.81 & 3.24 & 2.85 & 3.10 & Firmicutes & Bacilli & Bacillales & Fictibacillus arsenicus & 100 & KP307782.1 \\
\hline 5712 & 4.38 & 3.74 & 3.64 & 2.46 & 2.31 & Firmicutes & Bacilli & Bacillales & Bacillus vietnamensis & 98 & KP713658.1 \\
\hline 2557 & 1.72 & 3.67 & 0.40 & 1.68 & 3.18 & Firmicutes & Bacilli & Bacillales & $\begin{array}{l}\text { Bacillus } \\
\text { baekryungensis }\end{array}$ & 98 & KR045741.1 \\
\hline 1679 & 0.91 & 2.62 & 1.52 & 2.90 & 1.46 & Firmicutes & Bacilli & Bacillales & $\begin{array}{l}\text { Bacillus } \\
\text { oceanisediminis }\end{array}$ & 99 & LN774318.1 \\
\hline 4304 & 1.87 & 2.05 & 1.99 & 1.94 & 1.43 & Firmicutes & Bacilli & Bacillales & Bacillus idriensis & 99 & KR922323.1 \\
\hline 2159 & 0.08 & 0.40 & 0.81 & 2.17 & 3.17 & Firmicutes & Bacilli & Bacillales & $\begin{array}{l}\text { Bacillus } \\
\text { decolorationis }\end{array}$ & 99 & KF815234.1 \\
\hline 4206 & 0.60 & 1.00 & 0.08 & 1.11 & 1.33 & Firmicutes & Bacilli & Bacillales & Sporosarcina soli & 99 & AB682453.1 \\
\hline 5045 & n.d. & 0.93 & n.d. & n.d. & 6.83 & Proteobacteria & Gammaproteobacteria & Alteromonadales & Salinimonas lutimaris & 99 & NR_109101.1 \\
\hline 1173 & 0.83 & 0.97 & 1.07 & 0.69 & 0.71 & Proteobacteria & Gammaproteobacteria & Chromatiales & $\begin{array}{l}\text { Thioprofundum } \\
\text { lithotrophicum }\end{array}$ & 96 & NR_112829.1 \\
\hline 2203 & 0.21 & 0.21 & n.d. & 0.11 & 2.76 & Proteobacteria & Gammaproteobacteria & Oceanospirillales & $\begin{array}{l}\text { Microbulbifer } \\
\text { okinawensis }\end{array}$ & 99 & JQ765866.1 \\
\hline 1435 & 0.02 & 0.07 & 0.65 & 0.81 & 1.71 & Proteobacteria & Gammaproteobacteria & Pseudomonadales & $\begin{array}{l}\text { Psychrobacter } \\
\text { maritimus }\end{array}$ & 99 & KR709318.1 \\
\hline 2540 & n.d. & 0.04 & 1.25 & 1.79 & 0.08 & Proteobacteria & Gammaproteobacteria & Pseudomonadales & $\begin{array}{l}\text { Psychrobacter } \\
\text { piscatorii }\end{array}$ & 99 & KP715892.1 \\
\hline 4139 & 1.02 & 0.44 & 0.47 & 0.76 & 0.75 & Gemmatimonadetes & Gemmatimonadetes & - & $\begin{array}{l}\text { Ectothiorhodospira } \\
\text { salini }\end{array}$ & 86 & NR_104503.1 \\
\hline 4159 & n.d. & n.d. & 2.33 & n.d. & n.d. & Unclassified Prokaryotes & - & - & $\begin{array}{l}\text { Ammoniphilus } \\
\text { oxalaticus }\end{array}$ & 83 & Y14579.1 \\
\hline
\end{tabular}

n.d., not detected. ${ }^{a}$ Relative abundance expressed as percentage of the total sequences for each station.

hydrocarbons C5-C10) and the sedimentary organic matter, the prokaryotic abundance and biomass were significantly higher at pockmarks A162, A163, and A164 (Figure 3), suggesting a possible higher prokaryotic activity at those stations. Increased prokaryotic counts associated with active seeping (Werne et al., 2004; Pimenov et al., 2010) and mud volcanoes (Mills et al., 2003; Corinaldesi et al., 2011) have been already reported in other areas worldwide. Conversely, lower bacterial abundances in inactive pockmarks compared to surrounding sediments were reported in the North Sea (Haverkamp et al., 2014).

Previous investigation in seep-influenced sediments suggested that a high proportion of Archaea is present in these environments, especially in subsurface sediment layers (Orcutt et al., 2005; Corinaldesi et al., 2011). This increase in Archaea abundance may be due to the higher presence of methanotrophs, especially linked to the anaerobic oxidation of methane (Joye et al., 2004; Orcutt et al., 2005; Knittel and Boetius, 2009). Although estimate of Bacteria and Archaea relative contributions are influenced by the methodology selected (Xie et al., 2013), the general increase in Archaea with sediment depths in the first few meters below seafloor is generally described also in non-seep sediments (Lipp et al., 2008; Molari et al., 2012). Our data suggest a different trend for the shallow-water pockmarks sampled in this study. The community was dominated by Bacteria in all sampled stations, and, except for station A162 in the deep layer, BAR increased with increasing sediment depth. This observation, along with the increase in hydrocarbon concentration in the deeper sediment layers, suggests a role for the bacterial population in hydrocarbon degradation, potentially linked to the use of oxidized nitrogen species.

We investigated the microbial diversity in the surface sediments (0-1 cm layer) using $16 \mathrm{~S}$ rRNA pyrotag libraries. Our analysis revealed that the total diversity in the pockmarks was higher than that of the surrounding sediments (Figure 4). The overall diversity estimates (average Chaol of 2873) were in line with those reported by Ruff et al. (2015) in their global estimate of diversity in cold seep-associated sediments. However, the composition of the microbial communities associated with the pockmarks of the Adriatic Sea differed from previously studied cold-seeps and pockmarks worldwide.

In order to investigate whether the different assemblages were dominated by few or several phylotypes, we calculated the core microbiome for the sampled stations (i.e., the OTUs present in all sampled stations), common OTUs (i.e., shared among 


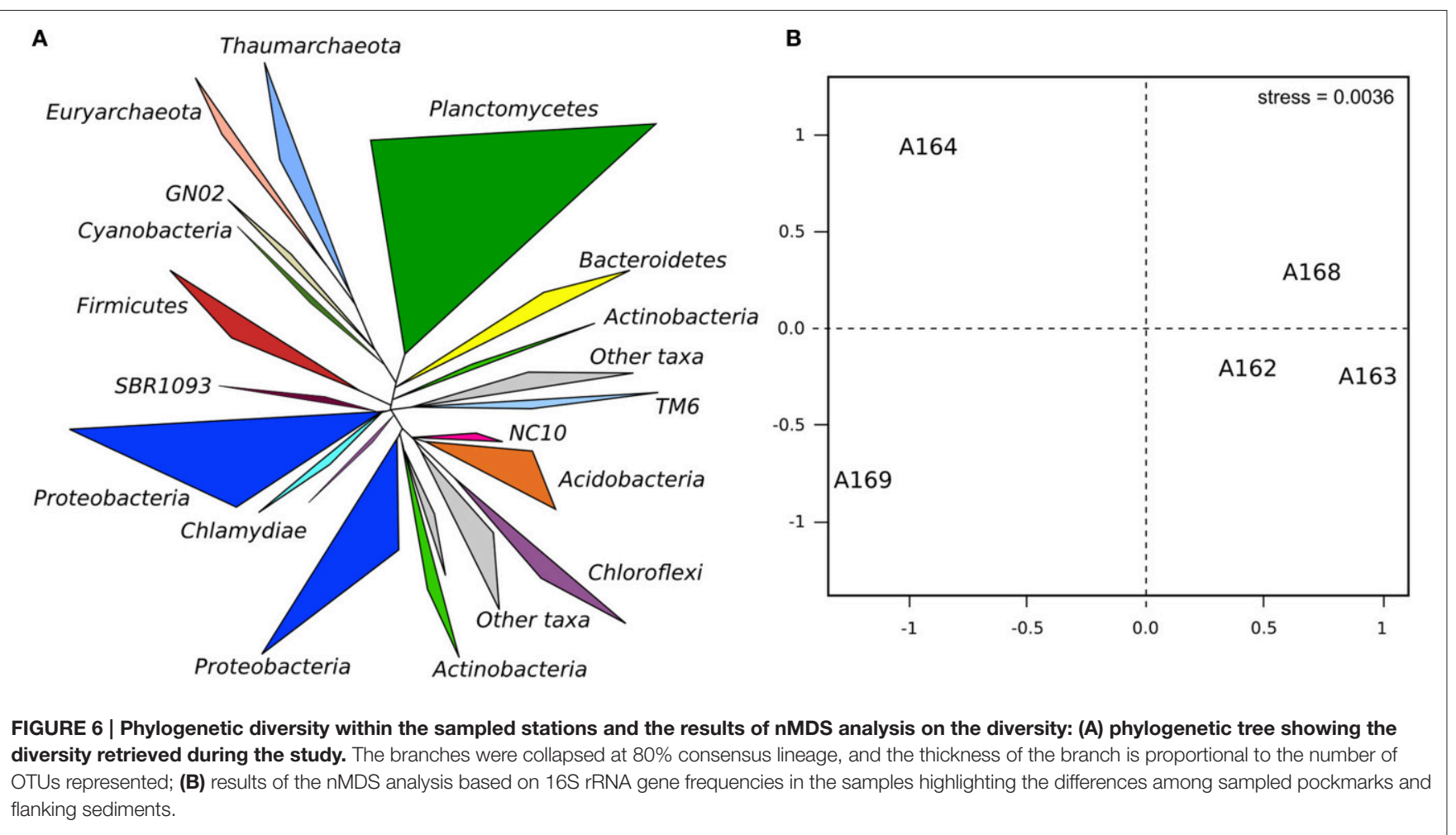

some stations) and station-specific OTUs (Figure 7). We used the obtained information to draw the "connectome" (i.e., the network of connection among shared OTUs in our dataset; Figure 5, circle e), visually representing the distribution of the OTUs network among the different samples. The visual analysis of the connectome can reveal the presence of pattern among the distribution of OTUs between stations. For instance, the presence of asymmetrical connection would indicate that certain OTUs are common only among some stations. Our results show that: (i) there is a high degree of symmetry of the connectome, implying that on average the shared OTUs are ubiquitous among all sampled stations; and (ii) the majority of the station specific OTUs are part of the unclassified sequences pool, leaving little margin for interpretation of their possible ecological role.

The obtained libraries were all dominated by sequences related to the phylum Firmicutes. Members of this group have been previously found to be abundant in other hydrocarbon enriched sediments and soils (Vivas et al., 2008; Reda, 2009; Kostka et al., 2011; Lamendella et al., 2014), and are commonly isolated when enriching for facultative anaerobic hydrocarbon degraders (Yakimov et al., 2007; Meckenstock and Mouttaki, 2011; Scherr et al., 2012; Lamendella et al., 2014; Abbasian et al., 2015). Further, high relative contribution of sequences assigned to the phylum Firmicutes were previously reported for the alkaline, athalassohaline lakes of the Wadi An Natrun valley in Egypt (Mesbah et al., 2007), the Gulf of Mexico and Cascadia Margin gas hydrate associated sediments (Lanoil et al., 2001; Knittel et al., 2003), in terrestrial mud volcanoes (Chang et al., 2012) and Arctic sediments (Hubert et al., 2009) in proximity of pockmark features. The majority of OTUs in the Firmicutes phylum were associated with the order Bacillales. The closest cultured relatives to the phylotypes retrieved from the pockmarks have heterotrophic metabolism, and most are known aliphatic or aromatic hydrocarbon utilizers. The most abundant OTU within the Bacillales was related to the B. aquimaris, known to metabolize a wide variety of organic compounds and amino acids and recently shown to grow on hydrocarbons as its sole carbon and energy source (Babatunde, 2012; Syakti et al., 2013; Fathepure, 2014). While Firmicutes are generally involved in the degradation and fermentation of complex organic substrates, these recent data indicate that members of this phylum are able to degrade hydrocarbons. Sequences related to the Actinobacteria (high $\mathrm{G}+\mathrm{C}$ division gram positive) were also retrieved in all investigated libraries (3.6\% on average). Members of this division are also often retrieved from hydrocarbon-contaminated areas, and constituted up to $40 \%$ of the clones from gas hydrate from the Nankai Trough (Colwell et al., 2004).

OTUs related to the Alteromonadales, Oceanospirillales, and Pseudomonadales, within the class Gammaproteobacteria, occurred frequently in the pockmarks. Members of the Alteromonadales have been shown to be primary players in the aerobic degradation of hydrocarbons (Rosenberg, 2013), and are reported as primary responders in studies that assessed the microbial community following the 2010 oil spill in the Gulf of Mexico (Joye et al., 2014; Kleindienst et al., 2016). Other groups of Gammaproteobacteria potentially involved in the degradation of hydrocarbon were Colwelliaceae, Pseudoalteromonadaceae, Oceanospirillaceae, and Alcanivoracaceae (Kostka et al., 2011; 


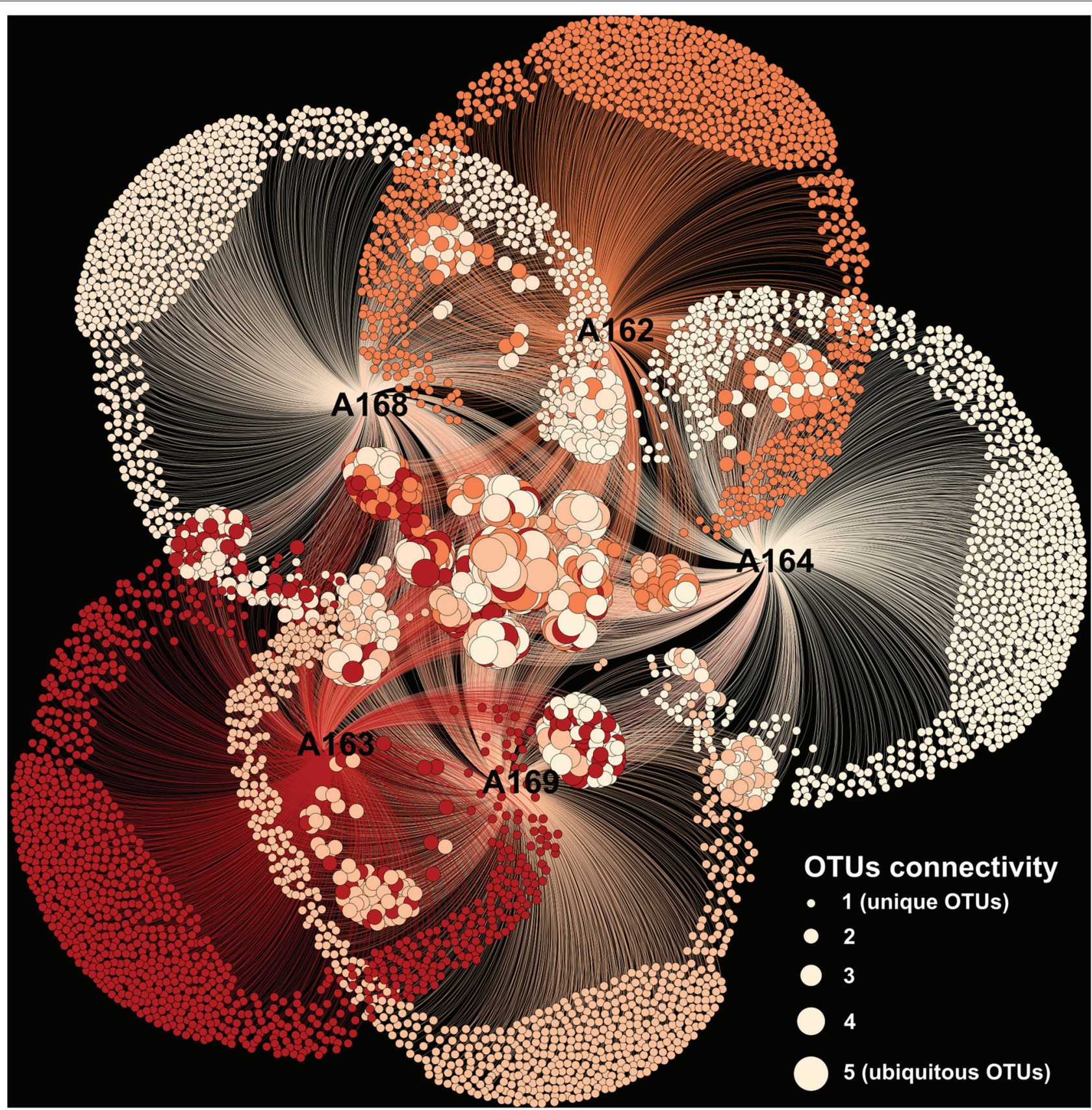

FIGURE 7 | Network analysis of the OTUs composition for each sampled station. The network was visualized using the Yifan Hu algorithm. OTUs are color-coded based on the station. The dimension of the circle is proportional to the in-degree connection, i.e., the number of station in which the OTU was detected.

Rosenberg, 2013; Joye et al., 2014; Kleindienst et al., 2016), although their relative abundance was lower. These groups have been described as abundant in water samples collected in hydrocarbon-contaminated areas (Kostka et al., 2011; Dubinsky et al., 2013).

A high number of sequences related to known thiotrophic and methylotrophic bacteria were recovered, belonging to the Thiotrichales and Chromatiales divisions in the Gammaproteobacteria, Methylacidiphilae in the Verrucomicrobia, and the Methylarcula in the Alphaproteobacteria division. Sequences relative to the order Chromatiales have been previously identified in deeper sediments of inactive pockmarks in the North Sea (Haverkamp et al., 2014). We also identified a high percentage of sequences belonging to the candidate division $\mathrm{NC10}$, albeit with a low similarity to the only known cultured relative, candidatus Methylomirabilis oxyfera. Members of this division have been identified in low abundance in a variety of aquatic habitats worldwide and are now 
believed to be responsible for the anaerobic oxidation of methane coupled to denitrification, using a new "intra-aerobic" pathway (Raghoebarsing et al., 2006; Knittel and Boetius, 2009; Ettwig et al., 2010). The presence of sequences related to candidate division NC10 in our samples suggests that nitrite-dependent anaerobic methane and hydrocarbon oxidation might be a mechanism of hydrocarbon utilization in the pockmarks. Similar reactions may be coupled to more recalcitrant substrates (i.e., aromatic compounds and alkanes) (Ettwig et al., 2010).

We also observed the presence of numerous phylotypes related to anaerobic/microaerophilic bacteria in our libraries. Aside from possible anaerobic methane or hydrocarbon degraders, we detected sequences associated with known sulfate reducers. Several phylotypes were associated with sequences closely related to members of the Mixococcales, candidate division NB1-j, Desulfuromonadaceae, Nitrospinaceae, and Geobacteraceae divisions. Sequences related to the syntrophic sulfate reducers order Syntrophobacterales were also retrieved in the libraries. Members of these divisions are capable of sulfate reduction both as energy metabolism (chemolithotrophy) or associated to a fermentative type of metabolism (Barton and Tomei, 1995), and are known to play a fundamental role in sulfur cycling. The co-occurrence of sulfate reducers and thiotrophic groups, such as members of the order Chromatiales, indicate that a complete sulfur cycle may be present in pockmark sediments, highlighting the complementary interplay between the carbon and sulfur cycles in these environments.

Numerous retrieved phylotypes were also involved in the cycling of nitrogen species. Sequences related to the phylum Nitrospirae, the order Nitrosomonadales of the Betaproteobacteria divison and Nitrospinaceae family within the Deltaproteobacteria were retrieved all at relative abundances between 0.1 and $0.5 \%$, suggesting potential for nitrite oxidation in the sampled sediments. Moreover, numerous phylotypes associated with the Firmicutes, Gammaproteobacteria, Deltaproteobacteria, and Alphaproteobacteria division are capable of respiring nitrate anaerobically. Sequences related to the Planctomycetes, representing the third most abundant bacterial phyla in our libraries, were potentially involved in nitrate reduction as well as anammox processes. Of the retrieved sequences belonging to the Planctomycetes pluylum, on average $1 \%$ was related to the Kueneniae class. Members of this group have been shown to be major players in the nitrogen cycle (Strous et al., 1999; Jetten et al., 2003), performing the anaerobic oxidation of ammonia. Cultured members of the Planctomycea, abundant in our libraries, include aerobic or facultative anaerobic chemoheterotrophs, some capable of nitrate reduction (Fuerst, 1995). The Planctomycetes phylum harbored the highest relative diversity in our libraries (Figure 6A), and was phylogenetically distant from cultured relatives. Similar results were previously reported for methane hydrate bearing sediments of the Nankai Trough (Reed et al., 2002), were the Planctomycetes represented the most diverse group identified in the study.

Overall, the presence of phylotypes related to anaerobic/microaerophilic bacteria in the $0-1 \mathrm{~cm}$ sediment layer of the pockmark sediments suggests a shallow penetration of oxygen. However, the presence of anaerobic niches in the surficial sediments may appear controversial. Under normal conditions, oxygen in finely grained marine sediments can diffuse up to several centimeters (Cai and Sayles, 1996; Glud, 2008). However, if high concentrations of organic carbon are present, like in the shallow-water sediments of the central Adriatic Sea, suboxic condition can be found within the first 10 $\mathrm{mm}$ (Yücel, 2013). Moreover, the effective penetration of oxygen is also influenced by the presence of upward fluid and gas venting (Yücel, 2013), and can be limited to the first few millimeters in cold-seeps and mud volcanoes (Niemann et al., 2006).

Archaea-related sequences were mostly represented by the phylum Thaumarchaeota, with members of the genus Nitrosopumilus being the most abundant. Previous studies showed that members of the Thaumarchaeota phylum drive $\mathrm{CO}_{2}$ fixation in deep waters coupled to ammonia oxidation (e.g., Könneke et al., 2005). The high abundance of sequences related to the Thaumarchaeota in all investigated libraries suggest an increased importance of carbon fixation linked to ammonia oxidation. Recently, sequences related to the Thaumarchaeota have been reported from diverse environments, including marine sediments (Auguet et al., 2009; Durbin and Teske, 2010) and basalts (Mason et al., 2008). We also identified sequences related to members of the Euryarchaeota, albeit at very low relative abundances. Sequences belonging to the class Themoplasmata, Methanobacteria, and Halobacteria occurred in very low abundances (i.e., below 0.1\%), while ANME groups were completely absent. Previous studies carried out in methanerich sediments, pockmarks and mud-volcanoes showed a high abundance of Euryarchaeota associated with anaerobic methane oxidizers consortium (ANME) (Boetius et al., 2000; Joye et al., 2004; Kniemeyer et al., 2007), which couples sulfate-reduction to the anaerobic oxidation of methane in seep environments (reviewed in Knittel and Boetius, 2009). Members of the ANME divisions are strict anaerobes and they are usually present in deeper sediments in the sulfate-methane transition zone, where sulfate-reduction and methane oxidation co-occur (Knittel and Boetius, 2009).

Proteobacteria and Planctomycetes had the highest number of station-specific OTUs in pockmark station A162, A163, and A164 (visible in the higher number of gray bands in Figure 5, circle b). This result implies that a specialized community is present in shallow-water pockmark sediments, and that shallowwater pockmarks harbor a prokaryotic community with a unique diversity signature. When compared to publicly available datasets from coastal waters, deep-sea hydrothermal vents, and deep-sea methane seeps, the sampled shallow-water pockmarks reveal a unique diversity pattern (Figure 8). Despite numerous phyla were shared among samples, the phylotypes associated with each environment were different, and pockmark libraries' obtained in this study presented unique groups not commonly found in the comparison libraries. The high abundance of unknown and unclassified sequences in pockmark stations suggest the presence of a considerable amount of microbial novelty, warranting further investigations, perhaps including culture-based approaches.

In conclusion, our results indicate that the pockmarks located in the proximity of the Middle Adriatic Ridge are associated with 


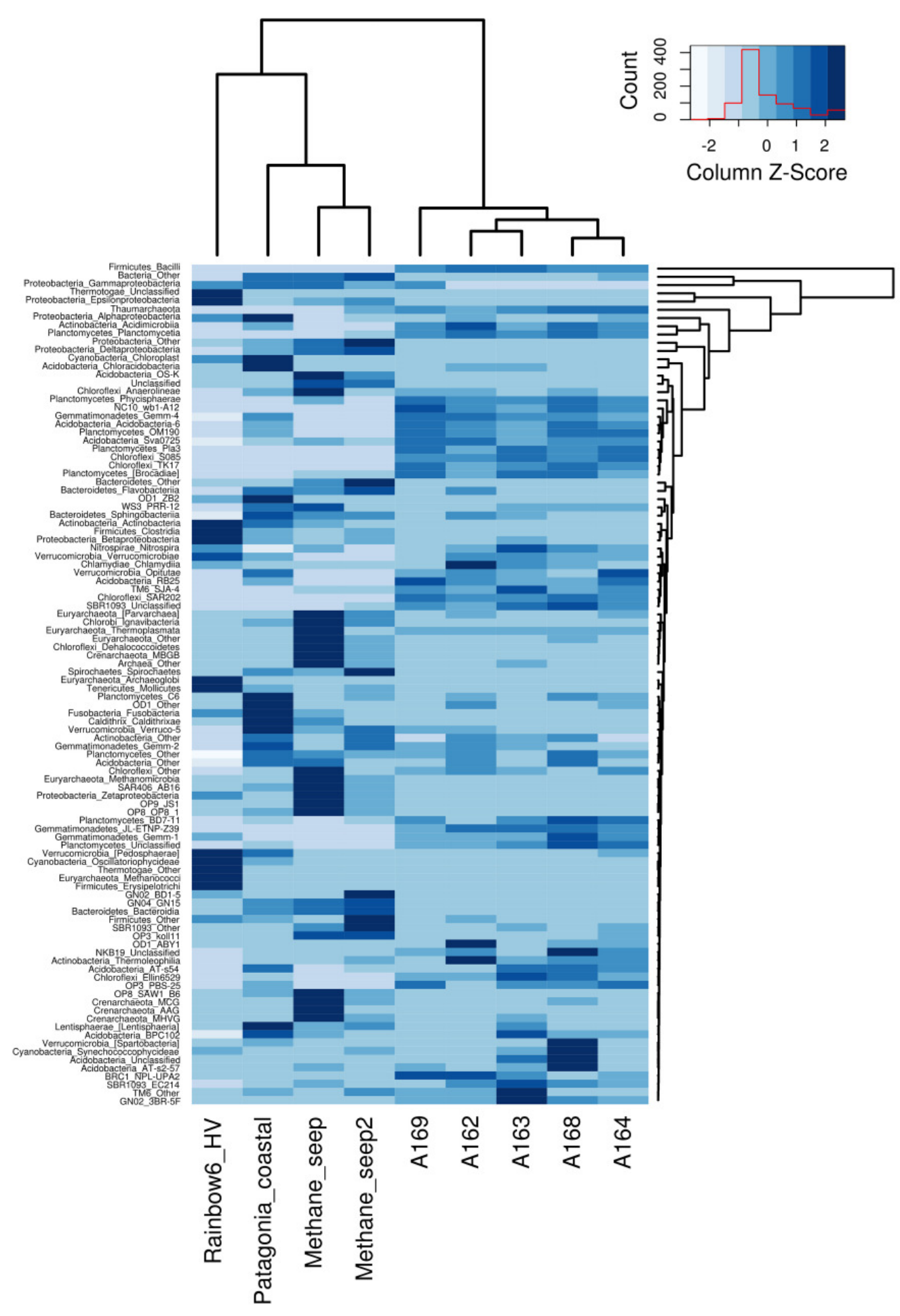

FIGURE 8 | Comparative 16S rRNA gene heatmap of diversity (at the class level) of shallow-water pockmark libraries (this study) against other 16S rRNA dataset publicly available.

a sedimentary hydrocarbon anomaly, suggesting that these sites are active, or have been active in the recent past. Microbiological analyses indicate that the community associated with pockmark sediments is more diverse and harbors higher abundances than those in surrounding sediments, potentially due to the higher availability of organic matter and hydrocarbon concentrations 
linked to active seeping. The diversity signature of the shallowwater pockmarks of the Adriatic Sea appears to be unique and comprised phylotypes related to bacteria associated with the cycling of sulfur and nitrate compounds, as well as numerous known hydrocarbon degraders. Altogether, this study suggests that shallow-water pockmarks positively influence the benthic diversity, providing specialized environmental niches harboring a wide range of metabolically diverse prokaryotes, warranting further interest in their investigation.

\section{AUTHOR CONTRIBUTIONS}

DG, FR, MT, and EM designed the research. DG, LA, MY, TB, and MT performed the sampling. DG, GD, FF, LA, DF, MY, and EM performed laboratory analyses. All authors contributed to the analysis and interpretation of the results and wrote the manuscript.

\section{FUNDING}

This work was partially supported by a Postdoctoral Fellowship from the Center for Dark Energy Biosphere Investigations [CDEBI, grant OCE-0939564] awarded to DG, by National Science Foundation grant OCE 11-24141 to CV, and European Science

\section{REFERENCES}

Abbasian, F., Lockington, R., Mallavarapu, M., and Naidu, R. (2015). A comprehensive review of aliphatic hydrocarbon biodegradation by bacteria. Appl. Biochem. Biotechnol. 176, 670-699. doi: 10.1007/s12010-015-1 603-5

Abramoff, M. D., Magalhães, P. J., and Ram, S. J. (2004). Image processing with ImageJ. Biophoton. Int. 11, 36-42.

Amann, R. (1995). Fluorescently labelled, rRNA-targeted oligonucleotide probes in the study of microbial ecology. Mol. Ecol. 4, 543-554. doi: 10.1111/j.1365294X.1995.tb00255.x

Amann, R. I., Binder, B. J., Olson, R. J., Chisholm, S. W., Devereux, R., and Stahl, D. A. (1990). Combination of $16 \mathrm{~S}$ rRNA-targeted oligonucleotide probes with flow cytometry for analyzing mixed microbial populations. Appl. Environ. Microbiol. $56,1919-1925$.

Auguet, J. C., Barberan, A., and Casamayor, E. O. (2009). Global ecological patterns in uncultured Archaea. ISME J. 4, 182-190. doi: 10.1038/ismej.2009.109

Babatunde, A. S. (2012). Alkane degradative potentials of bacteria isolated from the deep atlantic ocean of the gulf of guinea. J. Bioremed. Biodegr. 3:1000135. doi: 10.4172/2155-6199.1000135

Barton, L. L., and Tomei, F. A. (1995). "Characteristics and activities of sulfatereducing bacteria," in Sulfate-Reducing Bacteria Biotechnology Handbooks, ed L. L. Barton (New York, NY: Springer), 1-32.

Bastian, M., Heymann, S., and Jacomy, M. (2009). Gephi: An Open Source Software for Exploring and Manipulating Networks. Available online at: http://www.aaai. org/ocs/index.php/ICWSM/09/paper/view/154 (Accessed August 11, 2014).

Benedetti, M., Gorbi, S., Fattorini, D., D'Errico, G., Piva, F., Pacitti, D., et al. (2014). Environmental hazards from natural hydrocarbons seepage: Integrated classification of risk from sediment chemistry, bioavailability and biomarkers responses in sentinel species. Environ. Pollut. 185, 116-126. doi: 10.1016/j.envpol.2013.10.023

Boetius, A., Ravenschlag, K., Schubert, C. J., Rickert, D., Widdel, F., Gieseke, A., et al. (2000). A marine microbial consortium apparently mediating anaerobic oxidation of methane. Nature 407, 623-626. doi: 10.1038/35036572

Boitsov, S., Jensen, H. K. B., and Klungsøyr, J. (2009). Natural background and anthropogenic inputs of polycyclic aromatic hydrocarbons (PAH) in
Foundation EuroDeep BIOFUN grant CTM2007-28739-E to EM. This article commits to EU HERMIONE [contract no. 226354] and CoCoNet [contract no. 287844] programs, and the Italian MIUR flag Ritmare within the National Research Program 2011-2013. This publication was in part supported by the ELSI Origins Network (EON), which is supported by a grant from the John Templeton Foundation. The opinions expressed in this publication are those of the authors and do not necessarily reflect the views of the John Templeton Foundation. Porewater chemical measurements were supported by DEKOSIM Project (National Excellence Centre for Marine Ecosystem and Climate Research Deniz Ekosistem ve İklim Araştırmaları Merkezi, Project Code BAP-08-11-DPT.2012K120880), financed by the Ministry of Development of Turkey. This is ISMAR-CNR, Bologna scientific contribution n. 1842 .

\section{ACKNOWLEDGMENTS}

The authors wish to thank the master, crew and scientific staff of the R/V Urania during cruise ARCADIA for their skillful operation at sea. We thank Esra Ermis, Dr. Mustafa Kocak, Pinar Kulekci and Ramazan Ulger for technical support. The authors gratefully acknowledge the support of the Deep Carbon Observatory. sediments of South-Western Barents Sea. Mar. Environ. Res. 68, 236-245. doi: 10.1016/j.marenvres.2009.06.013

Bouloubassi, I., Nabais, E., Pancost, R. D., Lorre, A., and Taphanel, M.-H. (2009). First biomarker evidence for methane oxidation at cold seeps in the Southeast Atlantic (REGAB pockmark). Deep Sea Res. II Top. Stud. Oceanogr. 56, 2239-2247. doi: 10.1016/j.dsr2.2009.04.006

Cai, W.-J., and Sayles, F. L. (1996). Oxygen penetration depths and fluxes in marine sediments. Mar. Chem. 52, 123-131. doi: 10.1016/0304-4203(95)00081-X

Cambon-Bonavita, M. A., Nadalig, T., Roussel, E., Delage, E., Duperron, S., Caprais, J. C., et al. (2009). Diversity and distribution of methaneoxidizing microbial communities associated with different faunal assemblages in a giant pockmark of the Gabon continental margin. Deep Sea Res. II Top. Stud. Oceanogr. 56, 2248-2258. doi: 10.1016/j.dsr2.2009. 04.007

Caporaso, J. G., Bittinger, K., Bushman, F. D., DeSantis, T. Z., Andersen, G. L., and Knight, R. (2010a). PyNAST: a flexible tool for aligning sequences to a template alignment. Bioinformatics 26, 266-267. doi: 10.1093/bioinformatics/ btp636

Caporaso, J. G., Kuczynski, J., Stombaugh, J., Bittinger, K., Bushman, F. D., Costello, E. K., et al. (2010b). QIIME allows analysis of highthroughput community sequencing data. Nat. Methods 7, 335-336. doi: 10.1038/nmeth.f.303

Caporaso, J. G., Lauber, C. L., Walters, W. A., Berg-Lyons, D., Lozupone, C. A., Turnbaugh, P. J., et al. (2011). Global patterns of $16 \mathrm{~S}$ rRNA diversity at a depth of millions of sequences per sample. Proc. Natl. Acad. Sci. U.S.A. 108, 4516-4522. doi: 10.1073/pnas.1000080107

Chang, Y.-H., Cheng, T.-W., Lai, W.-J., Tsai, W.-Y., Sun, C.-H., Lin, L.-H., et al. (2012). Microbial methane cycling in a terrestrial mud volcano in eastern Taiwan. Environ. Microbiol. 14, 895-908. doi: 10.1111/j.1462-2920. 2011.02658.x

Colwell, F., Matsumoto, R., and Reed, D. (2004). A review of the gas hydrates, geology, and biology of the Nankai Trough. Chem. Geol. 205, 391-404. doi: 10.1016/j.chemgeo.2003.12.023

Conti, A., Stefanon, A., and Zuppi, G. M. (2002). Gas seeps and rock formation in the northern Adriatic Sea. Cont. Shelf Res. 22, 2333-2344. doi: 10.1016/S02784343(02)00059-6 
Corinaldesi, C., Dell'Anno, A., and Danovaro, R. (2011). Viral infections stimulate the metabolism and shape prokaryotic assemblages in submarine mud volcanoes. ISME J. 6, 1250-1259. doi: 10.1038/ismej.2011.185

Curzi, P. V. (2013). Metano. Vita e Storia di una Risorsa Pericolosa, 1st Edn. Rome: Aracne.

Curzi, P. V., and Veggiani, A. (1985). I pockmarks nel mare Adriatico centrale. Acta Nat. Ateneo Parm. 21, 79-90.

Daims, H., Brühl, A., Amann, R., Schleifer, K.-H., and Wagner, M. (1999). The domain-specific probe EUB338 is insufficient for the detection of all Bacteria: development and evaluation of a more comprehensive probe set. Syst. Appl. Microbiol. 22, 434-444. doi: 10.1016/S0723-2020(99) 80053-8

Dale, A. W., Sommer, S., Lomnitz, U., Montes, I., Treude, T., Gier, J., et al. (2014). Organic carbon production, mineralization and preservation on the Peruvian margin. Biogeosci. Discuss. 11, 13067-13126. doi: 10.5194/bgd-11-1306 7-2014

Dando, P. R. (2001). A Review of Pockmarks in the UK Part of the North Sea, with Particular Respect to their Biology. Technical report produced for Strategic Environmental Assessment, TR001, School of Ocean Sciences University of Wales-Bangor.

Dando, P. R., Austen, M. C., Burke, R. A., Kendall, M. A., Kennicutt, M. C., Judd, A. G., et al. (1991). Ecology of a North Sea pockmark with an active methane seep. Mar. Ecol. Progr. Ser. 70, 49-63. doi: 10.3354/meps070049

Danovaro, R. (2010). "Bioavalaible organic matter: total and enzymatically hydrolyzable proteins, carbohydrates, and lipids," in Methods for the Study of Deep-Sea Sediments-their Functioning and Biodiversity, ed R. Danovaro (Boca Raton, FL: Taylor \& Francis), 23-51.

DeSantis, T. Z., Hugenholtz, P., Larsen, N., Rojas, M., Brodie, E. L., Keller, K., et al. (2006). Greengenes, a chimera-checked 16S rRNA gene database and workbench compatible with ARB. Appl. Environ. Microbiol. 72, 5069-5072. doi: 10.1128/AEM.03006-05

Devol, A. H. (2015). Denitrification, anammox, and N2 production in marine sediments. Annu. Rev. Mar. Sci. 7, 403-423. doi: 10.1146/annurev-marine010213-135040

Dimitrov, L., and Woodside, J. (2003). Deep sea pockmark environments in the eastern Mediterranean. Mar. Geol. 195, 263-276. doi: 10.1016/S00253227(02)00692-8

Dubinsky, E. A., Conrad, M. E., Chakraborty, R., Bill, M., Borglin, S. E., Hollibaugh, J. T., et al. (2013). Succession of hydrocarbon-degrading bacteria in the aftermath of the deepwater horizon oil spill in the Gulf of Mexico. Environ. Sci. Technol. 47, 10860-10867. doi: 10.1021/es401676y

Durbin, A. M., and Teske, A. (2010). Sediment-associated microdiversity within the Marine Group I Crenarchaeota. Environ. Microbiol. Rep. 2, 693-703. doi: 10.1111/j.1758-2229.2010.00163.x

Edgar, R. C. (2010). Search and clustering orders of magnitude faster than BLAST. Bioinformatics 26, 2460-2461. doi: 10.1093/bioinformatics/btq461

Edgar, R. C., Haas, B. J., Clemente, J. C., Quince, C., and Knight, R. (2011). UCHIME improves sensitivity and speed of chimera detection. Bioinformatics 27, 2194-2200. doi: 10.1093/bioinformatics/btr381

Etiope, G., Panieri, G., Fattorini, D., Regoli, F., Vannoli, P., Italiano, F., et al. (2014). A thermogenic hydrocarbon seep in shallow Adriatic Sea (Italy): gas origin, sediment contamination and benthic foraminifera. Mar. Pet. Geol. 57, 283-293. doi: 10.1016/j.marpetgeo.2014.06.006

Ettwig, K. F., Butler, M. K., Le Paslier, D., Pelletier, E., Mangenot, S., Kuypers, M. M., et al. (2010). Nitrite-driven anaerobic methane oxidation by oxygenic bacteria. Nature 464, 543-548. doi: 10.1038/nature08883

Fabiano, M., Danovaro, R., and Fraschetti, S. (1995). A three-year time series of elemental and biochemical composition of organic matter in subtidal sandy sediments of the Ligurian Sea (northwestern Mediterranean). Cont. Shelf Res. 15, 1453-1469. doi: 10.1016/0278-4343(94)00088-5

Fathepure, B. Z. (2014). Recent studies in microbial degradation of petroleum hydrocarbons in hypersaline environments. Front. Microbiol. 5:173. doi: 10.3389/fmicb.2014.00173

Finetti, I., Bricchi, G., Del Ben, A., Pipan, M., and Xuan, Z. (1987). Geophysical study of the Adria plate. Mem. Soc. Geol. Ital. 40, 335-344.

Fleischer, P., Orsi, T., Richardson, M., and Anderson, A. (2001). Distribution of free gas in marine sediments: a global overview. Geo Mar. Lett. 21, 103-122. doi: $10.1007 / \mathrm{s} 003670100072$
Flores, G. E., Campbell, J. H., Kirshtein, J. D., Meneghin, J., Podar, M., Steinberg, J. I., et al. (2011). Microbial community structure of hydrothermal deposits from geochemically different vent fields along the Mid-Atlantic Ridge. Environ. Microbiol. 13, 2158-2171. doi: 10.1111/j.1462-2920.2011. 02463.x

Forwick, M., Baeten, N. J., and Vorren, T. O. (2009). Pockmarks in Spitsbergen fjords. Nor. J. Geol. 89, 65-77.

Fry, J. C. (1990). Direct methods and biomass estimation. Methods Microbiol. 22, 41-85. doi: 10.1016/S0580-9517(08)70239-3

Fuerst, J. A. (1995). The planctomycetes: emerging models for microbial ecology; evolution and cell biology. Microbiology 141, 1493-1506.

Geletti, R., Del Ben, A., Busetti, M., Ramella, R., and Volpi, V. (2008). Gas seeps linked to salt structures in the Central Adriatic Sea. Basin Res. 20, 473-487. doi: 10.1111/j.1365-2117.2008.00373.x

Giovannelli, D., d'Errico, G., Manini, E., Yakimov, M. M., and Vetriani, C. (2013a). Diversity and phylogenetic analyses of bacteria from a shallow-water hydrothermal vent in Milos island (Greece). Front. Microbiol. 4:184. doi: 10.3389/fmicb.2013.00184

Giovannelli, D., Molari, M., d'Errico, G., Baldrighi, E., Pala, C., and Manini, E. (2013b). Large-scale distribution and activity of prokaryotes in deep-sea surface sediments of the Mediterranean Sea and the adjacent Atlantic Ocean. PLoS ONE 8:e72996. doi: 10.1371/journal.pone.0072996

Glud, R. N. (2008). Oxygen dynamics of marine sediments. Mar. Biol. Res. 4, 243-289. doi: 10.1080/17451000801888726

Håvelsrud, O. E., Haverkamp, T. H., Kristensen, T., Jakobsen, K. S., and Rike, A. G. (2012). Metagenomic and geochemical characterization of pockmarked sediments overlaying the Troll petroleum reservoir in the North Sea. BMC Microbiol. 12:203. doi: 10.1186/1471-2180-12-203

Haverkamp, T. H. A., Hammer, Ø., and Jakobsen, K. S. (2014). Linking geology and microbiology: inactive pockmarks affect sediment microbial community structure. PLoS ONE 9:e85990. doi: 10.1371/journal.pone.0085990

Head, I. M., Jones, D. M., and Röling, W. F. M. (2006). Marine microorganisms make a meal of oil. Nat. Rev. Microbiol. 4, 173-182. doi: 10.1038/nrmicro1348

Hedges, J. I., and Keil, R. G. (1995). Sedimentary organic matter preservation: an assessment and speculative synthesis. Mar. Chem. 49, 81-115. doi: 10.1016/0304-4203(95)00008-F

Hinrichs, K.-U., and Boetius, A. (2003). "The anaerobic oxidation of methane: new insights in microbial ecology and biogeochemistry," in Ocean Margin Systems, eds P. D. G. Wefer, D. D. Billett, D. D. Hebbeln, P. D. B. B. Jørgensen, P. D. M. Schlüter, and D. T. C. E. van Weering (Berlin: Springer), 457-477. Available online at: http://link.springer.com/chapter/10.1007/978-3-662-05127-6_28 (Accessed March 25, 2014).

Hovland, M., and Curzi, P. V. (1989). Gas seepage and assumed mud diapirism in the Italian central Adriatic Sea. Mar. Pet. Geol. 6, 161-169. doi: 10.1016/02648172(89)90019-6

Hovland, M., Gardner, J. V., and Judd, A. G. (2002). The significance of pockmarks to understanding fluid flow processes and geohazards. Geofluids 2, 127-136. doi: 10.1046/j.1468-8123.2002.00028.x

Hovland, M., Heggland, R., De Vries, M. H., and Tjelta, T. I. (2010). Unitpockmarks and their potential significance for predicting fluid flow. Mar. Pet Geol. 27, 1190-1199. doi: 10.1016/j.marpetgeo.2010.02.005

$\mathrm{Hu}, \mathrm{Y}$. (2005). Efficient, high-quality force-directed graph drawing. Math. J. 10, $37-71$.

Hubert, C., Loy, A., Nickel, M., Arnosti, C., Baranyi, C., Brüchert, V., et al. (2009). A constant flux of diverse thermophilic bacteria into the cold arctic seabed. Science 325, 1541-1544. doi: 10.1126/science.1174012

Jaekel, U., Musat, N., Adam, B., Kuypers, M., Grundmann, O., and Musat, F. (2013). Anaerobic degradation of propane and butane by sulfate-reducing bacteria enriched from marine hydrocarbon cold seeps. ISME J. 7, 885-895. doi: 10.1038/ismej.2012.159

Jetten, M. S. M., Sliekers, O., Kuypers, M., Dalsgaard, T., Niftrik, L., van Cirpus, I., et al. (2003). Anaerobic ammonium oxidation by marine and freshwater planctomycete-like bacteria. Appl. Microbiol. Biotechnol. 63, 107-114. doi: 10.1007/s00253-003-1422-4

Joye, S. B., Boetius, A., Orcutt, B. N., Montoya, J. P., Schulz, H. N., Erickson, M. J., et al. (2004). The anaerobic oxidation of methane and sulfate reduction in sediments from Gulf of Mexico cold seeps. Chem. Geol. 205, 219-238. doi: 10.1016/j.chemgeo.2003.12.019 
Joye, S. B., Teske, A. P., and Kostka, J. E. (2014). Microbial dynamics following the macondo oil well blowout across gulf of mexico environments. Bioscience 64, 766-777. doi: 10.1093/biosci/biu121

Judd, A. A. G., and Hovland, M. (2007). Seabed Fluid Flow: The Impact of Geology, Biology And the Marine Environment. Cambridge, UK: Cambridge University Press.

Kleindienst, S., Grim, S., Sogin, M., Bracco, A., Crespo-Medina, M., and Joye, S. B. (2016). Diverse, rare microbial taxa responded to the Deepwater Horizon deep-sea hydrocarbon plume. ISME J. 10, 400-415. doi: 10.1038/ismej. 2015.121

Kniemeyer, O., Musat, F., Sievert, S. M., Knittel, K., Wilkes, H., Blumenberg, M., et al. (2007). Anaerobic oxidation of short-chain hydrocarbons by marine sulphate-reducing bacteria. Nature 449, 898-901. doi: 10.1038/nature06200

Knittel, K., and Boetius, A. (2009). Anaerobic oxidation of methane: progress with an unknown process. Annu. Rev. Microbiol. 63, 311-334. doi: 10.1146/annurev.micro.61.080706.093130

Knittel, K., Boetius, A., Lemke, A., Eilers, H., Lochte, K., Pfannkuche, O., et al. (2003). Activity, distribution, and diversity of sulfate reducers and other bacteria in sediments above gas hydrate (Cascadia Margin, Oregon). Geomicrobiol. J. 20, 269-294. doi: 10.1080/01490450303896

Koçak, M., Theodosi, C., Zarmpas, P., Séguret, M. J. M., Herut, B., Kallos, G., et al. (2012). Influence of mineral dust transport on the chemical composition and physical properties of the Eastern Mediterranean aerosol. Atmos. Environ. 57, 266-277. doi: 10.1016/j.atmosenv.2012.04.006

Könneke, M., Bernhard, A. E., de la Torre, J. R., Walker, C. B., Waterbury, J. B., and Stahl, D. A. (2005). Isolation of an autotrophic ammonia-oxidizing marine archaeon. Nature 437, 543-546. doi: 10.1038/nature03911

Koppelmann, R., Weikert, H., Halsband-Lenk, C., and Jennerjahn, T. (2004). Mesozooplankton community respiration and its relation to particle flux in the oligotrophic eastern Mediterranean. Glob. Biogeochem. Cycles 18:GB1039. doi: 10.1029/2003gb002121

Kostka, J. E., Prakash, O., Overholt, W. A., Green, S. J., Freyer, G., Canion, A., et al. (2011). Hydrocarbon-degrading bacteria and the bacterial community response in Gulf of Mexico Beach Sands impacted by the deepwater horizon oil spill. Appl. Environ. Microbiol. 77, 7962-7974. doi: 10.1128/AEM.05402-11

Krzywinski, M., Schein, J., Birol, I., Connors, J., Gascoyne, R., Horsman, D., et al. (2009). Circos: an information aesthetic for comparative genomics. Genome Res. 19, 1639-1645. doi: 10.1101/gr.092759.109

Lamendella, R., Strutt, S., Borglin, S., Chakraborty, R., Tas, N., Mason, O. U., et al. (2014). Assessment of the deepwater horizon oil spill impact on Gulf coast microbial communities. Front. Microbiol. 5:130. doi: 10.3389/fmicb.2014. 00130

Lanoil, B. D., Sassen, R., La Duc, M. T., Sweet, S. T., and Nealson, K. H. (2001). Bacteria and archaea physically associated with gulf of mexico gas hydrates. Appl. Environ. Microbiol. 67, 5143-5153. doi: 10.1128/AEM.67.11.5143-5153. 2001

Lazar, C. S., Dinasquet, J., L'Haridon, S., Pignet, P., and Toffin, L. (2011). Distribution of anaerobic methane-oxidizing and sulfate-reducing communities in the G11 Nyegga pockmark, Norwegian Sea. Antonie Van Leeuwenhoek 100, 639-653. doi: 10.1007/s10482-011-9620-z

Levin, L. A. (2005). Ecology of cold seep sediments: interactions of fauna with flow, chemistry and microbes. Ocean Mar. Biol. Annu. Rev. 43, 1-46. doi: 10.1201/9781420037449.ch1

Lipp, J. S., Morono, Y., Inagaki, F., and Hinrichs, K. U. (2008). Significant contribution of Archaea to extant biomass in marine subsurface sediments. Nature 454, 991-994. doi: 10.1038/nature07174

Luna, G. M., Manini, E., and Danovaro, R. (2002). Large fraction of dead and inactive bacteria in coastal marine sediments: comparison of protocols for determination and ecological significance. Appl. Environ. Microbiol. 68, 3509-3513. doi: 10.1128/AEM.68.7.3509-351 3.2002

Manne, A. S., and Richels, R. G. (2001). An alternative approach to establishing trade-offs among greenhouse gases. Nature 410, 675-677. doi: $10.1038 / 35070541$

Mason, O. U., Hazen, T. C., Borglin, S., Chain, P. S. G., Dubinsky, E. A., Fortney, J. L., et al. (2012). Metagenome, metatranscriptome and single-cell sequencing reveal microbial response to Deepwater Horizon oil spill. ISME J. 6, 1715-1727. doi: 10.1038 /ismej.2012.59
Mason, O. U., Di Meo-Savoie, C. A., Van Nostrand, J. D., Zhou, J., Fisk, M. R., and Giovannoni, S. J. (2008). Prokaryotic diversity, distribution, and insights into their role in biogeochemical cycling in marine basalts. ISME J. 3, 231-242. doi: 10.1038/ismej.2008.92

Mazzotti, L., Segantini, S., Tramontana, M., and Wezel, F. C. (1987). Classification and distribution of pockmarks in the Jabuka Trough (central Adriatic). Boll. Oceanol. Teor. Ed Appl. 5, 237-250.

Meckenstock, R. U., and Mouttaki, H. (2011). Anaerobic degradation of nonsubstituted aromatic hydrocarbons. Curr. Opin. Biotechnol. 22, 406-414. doi: 10.1016/j.copbio.2011.02.009

Mesbah, N. M., Abou-El-Ela, S. H., and Wiegel, J. (2007). Novel and unexpected prokaryotic diversity in water and sediments of the alkaline, hypersaline lakes of the wadi an natrun, egypt. Microb. Ecol. 54, 598-617. doi: 10.1007/s00248006-9193-y

Merkel, A. Y., Chernykh, N. A., Kanapatskii, T. A., and Pimenov, N. V. (2010). Detection of methanotrophic archaea in pockmark sediments (Gdansk Deep, Baltic Sea) by sequence analysis of the gene encoding the $\alpha$ subunit of methyl-coenzyme M reductase. Microbiology 79, 849-852. doi: $10.1134 /$ S0026261710060196

Mills, H. J., Hodges, C., Wilson, K., MacDonald, I. R., and Sobecky, P. A. (2003). Microbial diversity in sediments associated with surface-breaching gas hydrate mounds in the Gulf of Mexico. FEMS Microbiol. Ecol. 46, 39-52. doi: 10.1016/S0168-6496(03)00191-0

Molari, M., Giovannelli, D., d'Errico, G., and Manini, E. (2012). Factors influencing prokaryotic community structure composition in sub-surface coastal sediments. Estuar. Coast. Shelf Sci. 97, 141-148. doi: 10.1016/j.ecss.2011. 11.036

Neurauter, T. W., and Roberts, H. H. (1994). Three generations of mud volcanoes on the Louisiana continental slope. Geo Mar. Lett. 14, 120-125. doi: 10.1007/BF01203723

Newton, R., Cunningham, R., and Schubert, C. (1980). "Mud volcanoes and pockmarks: seafloor engineering hazards or geological curiosities?” in The Offshore Technology Conference (Houston, TX). doi: 10.4043/3729-MS

Nickel, J. C., di Primio, R., Kallmeyer, J., Hammer, Ø., Horsfield, B., Stoddart, D., et al. (2013). Tracing the origin of thermogenic hydrocarbon signals in pockmarks from the southwestern Barents Sea. Org. Geochem. 63, 73-84. doi: 10.1016/j.orggeochem.2013.08.008

Niemann, H., Lösekann, T., de Beer, D., Elvert, M., Nadalig, T., Knittel, K., et al. (2006). Novel microbial communities of the Haakon Mosby mud volcano and their role as a methane sink. Nature 443, 854-858. doi: 10.1038/nature 05227

Nunoura, T., Takaki, Y., Kazama, H., Hirai, M., Ashi, J., Imachi, H., et al. (2012). Microbial diversity in deep-sea methane seep sediments presented by SSU rRNA gene tag sequencing. Microb. Environ. 27, 382-390. doi: 10.1264/jsme2.ME12032

Oksanen, J., Blanchet, F. G., Kindt, R., Legendre, P., Minchin, P. R., O’Hara, R. B., et al. (2012). vegan: Community Ecology Package. Available online at: http://CRAN.R-project.org/package=vegan

Olu-Le Roy, K., Caprais, J.-C., Fifis, A., Fabri, M.-C., Galéron, J., Budzinsky, H., et al. (2007). Cold-seep assemblages on a giant pockmark off West Africa: spatial patterns and environmental control. Mar. Ecol. 28, 115-130. doi: 10.1111/j.1439-0485.2006.00145.x

Olu-Le Roy, K., Sibuet, M., Fiala-Médioni, A., Gofas, S., Salas, C., Mariotti, A., et al. (2004). Cold seep communities in the deep eastern Mediterranean Sea: composition, symbiosis and spatial distribution on mud volcanoes. Deep Sea Res. I Oceanogr. Res. Pap. 51, 1915-1936. doi: 10.1016/j.dsr.2004. 07.004

Orcutt, B., Boetius, A., Elvert, M., Samarkin, V., and Joye, S. B. (2005). Molecular biogeochemistry of sulfate reduction, methanogenesis and the anaerobic oxidation of methane at Gulf of Mexico cold seeps. Geochim. Cosmochim. Acta 69, 4267-4281. doi: 10.1016/j.gca.2005.04.012

Parkes, R. J., Cragg, B. A., and Wellsbury, P. (2000). Recent studies on bacterial populations and processes in subseafloor sediments: a review. Hydrogeol. J. 8, 11-28. doi: 10.1007/PL00010971

Pernthaler, A., Pernthaler, J., and Amann, R. (2002). Fluorescence in situ hybridization and catalyzed reporter deposition for the identification of marine bacteria. Appl. Environ. Microbiol. 68, 3094-3101. doi: 10.1128/AEM.68.6.30943101.2002 
Pilcher, R., and Argent, J. (2007). Mega-pockmarks and linear pockmark trains on the West African continental margin. Mar. Geol. 244, 15-32. doi: 10.1016/j.margeo.2007.05.002

Pimenov, N. V., Ulyanova, M. O., Kanapatsky, T. A., Veslopolova, E. F., Sigalevich, P. A., and Sivkov, V. V. (2010). Microbially mediated methane and sulfur cycling in pockmark sediments of the Gdansk Basin, Baltic Sea. Geo Mar. Lett. 30, 439-448. doi: 10.1007/s00367-010-0200-4

Pirrung, M., Kennedy, R., Caporaso, J. G., Stombaugh, J., Wendel, D., and Knight, R. (2011). TopiaryExplorer: visualizing large phylogenetic trees with environmental metadata. Bioinformatics 27, 3067-3069. doi: 10.1093/bioinformatics/btr517

Piva, F., Ciaprini, F., Onorati, F., Benedetti, M., Fattorini, D., Ausili, A., et al. (2011). Assessing sediment hazard through a weight of evidence approach with bioindicator organisms: a practical model to elaborate data from sediment chemistry, bioavailability, biomarkers and ecotoxicological bioassays. Chemosphere 83, 475-485. doi: 10.1016/j.chemosphere.2010. 12.064

Pusceddu, A., Dell'Anno, A., Fabiano, M., and Danovaro, R. (2009). Quantity and bioavailability of sediment organic matter as signatures of benthic trophic status. Mar. Ecol. Prog. Ser. 375, 41-52. doi: 10.3354/meps 07735

R Development Core Team (2010). R: A Language and Environment for Statistical Computing. Available online at: http://www.R-project.org

Raghoebarsing, A. A., Pol, A., van de Pas-Schoonen, K. T., Smolders, A. J. P., Ettwig, K. F., Rijpstra, W. I. C., et al. (2006). A microbial consortium couples anaerobic methane oxidation to denitrification. Nature 440, 918-921. doi: 10.1038 /nature 04617

Reda, A. B. (2009). Bacterial bioremediation of polycyclic aromatic hydrocarbons in heavy oil contaminated soil. J. Appl. Sci. Res. 11, 197-201.

Reeburgh, W. S. (2007). Oceanic methane biogeochemistry. Chem. Rev. 107, 486-513. doi: $10.1021 / \mathrm{cr} 050362 \mathrm{v}$

Reed, D. W., Fujita, Y., Delwiche, M. E., Blackwelder, D. B., Sheridan, P. P., Uchida, T., et al. (2002). Microbial communities from methane hydrate-bearing deep marine sediments in a forearc basin. Appl. Environ. Microbiol. 68, 3759-3770. doi: 10.1128/AEM.68.8.3759-3770.2002

Rosenberg, D. E. (2013). "Hydrocarbon-oxidizing bacteria," in The Prokaryotes, eds E. Rosenberg, E. F. DeLong, S. Lory, E. Stackebrandt, and F. Thompson (Berlin: Springer), 201-214. Available online at: http://link. springer.com/referenceworkentry/10.1007/978-3-642-30141-4_66 (Accessed July 24, 2015).

Ruff, S. E., Biddle, J. F., Teske, A. P., Knittel, K., Boetius, A., and Ramette, A. (2015). Global dispersion and local diversification of the methane seep microbiome. Proc. Natl. Acad. Sci. U.S.A. 112, 4015-4020. doi: 10.1073/pnas.14218 65112

Sandulli, R., Miljutin, D., Angeletti, L., and Taviani, M. (2015). Meiobenthos and nematode assemblages from different deep-sea habitats of the Strait of Sicily (Central Mediterranean Sea). Mediterr. Mar. Sci. 16, 402-412. doi: 10.12681/ mms.1145

Santinelli, C., Nannicini, L., and Seritti, A. (2010). DOC dynamics in the meso and bathypelagic layers of the Mediterranean Sea. Deep Sea Res. II Top. Stud. Oceanogr. 57, 1446-1459. doi: 10.1016/j.dsr2.2010.02.014

Scherr, K. E., Lundaa, T., Klose, V., Bochmann, G., and Loibner, A. P. (2012). Changes in bacterial communities from anaerobic digesters during petroleum hydrocarbon degradation. J. Biotechnol. 157, 564-572. doi: 10.1016/j.jbiotec.2011.09.003

Schloss, P. D., and Handelsman, J. (2005). Introducing DOTUR, a computer program for defining operational taxonomic units and estimating species richness. Appl. Environ. Microbiol. 71, 1501-1506. doi: 10.1128/AEM.71.3.1501-1506.2005

Simon, M., and Azam, F. (1989). Protein content and protein synthesis rates of planktonic marine bacteria. Mar. Ecol. Prog. Ser. 51, 201-213. doi: 10.3354/meps051201

Stahl, D., and Amann, R. (1991). "Development and application of nucleic acid probes in bacterial systematics," in Nucleic Acid Techniques in Bacterial Systematics, eds E. Stackebrandt and M. Goodfellow (Chichester: John Wiley \& Sons Ltd.), 205-248.

Stefanon, A. (1967). Formazioni rocciose del bacino dell'Alto Adriatico. Atti Ist. Ven. Sci. Lett. 125, 79-85.
Stefanon, A., Rabitti, A., and Boldrin, A. (1983). Gas-charged sediments and pockmarks in Adriatic Sea. Thalass. Jugosl. 19, 53-55.

Strous, M., Fuerst, J. A., Kramer, E. H. M., Logemann, S., Muyzer, G., van de Pas-Schoonen, K. T., et al. (1999). Missing lithotroph identified as new planctomycete. Nature 400, 446-449. doi: 10.1038/ 22749

Syakti, A. D., Yani, M., Hidayati, N. V., Siregar, A. S., Doumenq, P., and Sudiana, I. M. M. (2013). The bioremediation potential of hydrocarbonoclastic bacteria isolated from a mangrove contaminated by petroleum hydrocarbons on the Cilacap Coast, Indonesia. Bioremed. J. 17, 11-20. doi: 10.1080/10889868.2012.731446

Taviani, M. (2011). “The deep-sea chemoautotroph microbial world as experienced by the mediterranean metazoans through time," in Advances in Stromatolite Geobiology (Berlin: Springer Berlin Heidelberg), 277-295. Available online at: http://link.springer.com/10.1007/978-3-642-10415-2_18 (Accessed May 27, 2013).

Taviani, M. (2014). "Marine chemosynthesis in the mediterranean sea," in The Mediterranean Sea, eds S. Goffredo and Z. Dubinsky (Springer Netherlands), 69-83. Available online at: http://link.springer.com/chapter/10.1007/978-94007-6704-1_5 (Accessed March 25, 2014).

Taviani, M., Angeletti, L., Ceregato, A., Foglini, F., Froglia, C., and Trincardi, F. (2013). The Gela Basin pockmark field in the strait of Sicily (Mediterranean Sea): chemosymbiotic faunal and carbonate signatures of postglacial to modern cold seepage. Biogeosci. Discuss. 10, 967-1009. doi: 10.5194/bgd-10-96 $7-2013$

Teira, E., Reinthaler, T., Pernthaler, A., Pernthaler, J., and Herndl, G. J. (2004). Combining catalyzed reporter deposition-fluorescence in situ hybridization and microautoradiography to detect substrate utilization by bacteria and archaea in the deep ocean. Appl. Environ. Microbiol. 70, 4411-4414. doi: 10.1128/AEM.70.7.4411-4414.2004

Trincardi, F., Cattaneo, A., Correggiari, A., and Ridente, D. (2004). Evidence of soft sediment deformation, fluid escape, sediment failure and regional weak layers within the late Quaternary mud deposits of the Adriatic Sea. Mar. Geol. 213, 91-119. doi: 10.1016/j.margeo.2004.10.003

Tuğrul, S., Murray, J. W., Friederich, G. E., and Salihoğlu, I. (2014). Spatial and temporal variability in the chemical properties of the oxic and suboxic layers of the Black Sea. J. Mar. Syst. 135, 29-43. doi: 10.1016/j.jmarsys.2013. 09.008

Underwood, A. (1991). Beyond BACI: experimental designs for detecting human environmental impacts on temporal variations in natural populations. Mar. Freshw. Res. 42, 569-587. doi: 10.1071/ MF9910569

Vetriani, C., Speck, M. D., Ellor, S. V., Lutz, R. A., and Starovoytov, V. (2004). Thermovibrio ammonificans sp. nov., a thermophilic, chemolithotrophic, nitrate-ammonifying bacterium from deep-sea hydrothermal vents. Int. J. Syst. Evol. Microbiol. 54, 175-181. doi: 10.1099/ijs.0. 02781-0

Vivas, A., Moreno, B., del Val, C., Macci, C., Masciandaro, G., and Benitez, E. (2008). Metabolic and bacterial diversity in soils historically contaminated by heavy metals and hydrocarbons. J. Environ. Monit. 10, 1287. doi: $10.1039 / \mathrm{b} 808567 \mathrm{f}$

Wakeham, S. G., and Canuel, E. A. (2006). "Degradation and preservation of organic matter in marine sediments," in Marine Organic Matter: Biomarkers, Isotopes and DNA, ed J. K. Volkman (Berlin; Heidelberg: Springer), 295-321. doi: 10.1007/698_2_009

Wang, Q., Garrity, G. M., Tiedje, J. M., and Cole, J. R. (2007). Naïve bayesian classifier for rapid assignment of rRNA sequences into the new bacterial taxonomy. Appl. Environ. Microbiol. 73, 5261-5267. doi: 10.1128/AEM.000 62-07

Watson, R. T. (2001). Climate Change 2001. Synthesis Report: Third Assessment Report of the Intergovernmental Panel on Climate Change. Cambridge University Press.

Werne, J. P., Haese, R. R., Zitter, T., Aloisi, G., Bouloubassi, I., Heijs, S., et al. (2004). Life at cold seeps: a synthesis of biogeochemical and ecological data from Kazan mud volcano, eastern Mediterranean Sea. Chem. Geol. 205, 367-390. doi: 10.1016/j.chemgeo.2003.12.031

Xie, S., Lipp, J. S., Wegener, G., Ferdelman, T. G., and Hinrichs, K.-U. (2013). Turnover of microbial lipids in the deep biosphere and growth of benthic 
archaeal populations. Proc. Natl. Acad. Sci. U.S.A. 110, 6010-6014. doi: 10.1073/pnas.1218569110

Yakimov, M. M., Timmis, K. N., and Golyshin, P. N. (2007). Obligate oil-degrading marine bacteria. Curr. Opin. Biotechnol. 18, 257-266. doi: 10.1016/j.copbio.2007.04.006

Yücel, M. (2013). Down the thermodynamic ladder: a comparative study of marine redox gradients across diverse sedimentary environments. Estuar. Coast. Shelf Sci. 131, 83-92. doi: 10.1016/j.ecss.2013.07.013

Zeppilli, D., Canals, M., and Danovaro, R. (2012). Pockmarks enhance deep-sea benthic biodiversity: a case study in the western Mediterranean Sea. Divers. Distrib. 18, 832-846. doi: 10.1111/j.1472-4642.2011.00859.x
Conflict of Interest Statement: The authors declare that the research was conducted in the absence of any commercial or financial relationships that could be construed as a potential conflict of interest.

Copyright () 2016 Giovannelli, d'Errico, Fiorentino, Fattorini, Regoli, Angeletti, Bakran-Petricioli, Vetriani, Yücel, Taviani and Manini. This is an open-access article distributed under the terms of the Creative Commons Attribution License (CC BY). The use, distribution or reproduction in other forums is permitted, provided the original author(s) or licensor are credited and that the original publication in this journal is cited, in accordance with accepted academic practice. No use, distribution or reproduction is permitted which does not comply with these terms. 